\title{
The Evolution of Federal Reserve Policy and the Impact of Monetary Policy Surprises on Asset Prices
}

\author{
Brett W. Fawley and Christopher J. Neely
}

\begin{abstract}
This article describes the joint evolution of Federal Reserve policy and the study of the impact of monetary policy surprises on high-frequency asset prices. Since the 1970s, the Federal Open Market Committee has clarified its objectives and modified its procedures to become more transparent and predictable. Researchers have had to account for these changes to procedures and perceived objectives in developing methods to study the effects of monetary surprises. Unexpected changes to the Committee's federal funds target and postmeeting statements strongly and consistently affect asset prices, including interest rates, exchange rates, and (for target changes) stock prices. The study of monetary surprises on asset prices provides important insight for policymakers, financial market participants, and economic models. (JEL E52, E58, G14)
\end{abstract}

Federal Reserve Bank of St. Louis Review, First Quarter 2014, 96(1), pp. 73-109.

S ince the 1970s, monetary policy has been the primary macroeconomic stabilization instrument. In light of this fact, many researchers have studied how monetary policy affects asset prices, consumer prices, output, and employment to improve such policy. This large literature has used two main methods to study the effect of monetary shocks on macroeconomic variables: vector autoregressions (VARs) and studies of high-frequency monetary shocks on asset prices. $^{1}$

VARs offer the advantage of directly studying the effects of monetary policy shocks on key variables - prices, output, and employment—rather than indirectly studying them through their effects on asset prices (see Litterman and Weiss, 1985; Strongin,1995; Edelberg and Marshall, 1996; Evans and Marshall, 1998; Bernanke and Mihov, 1998; and Christiano, Eichenbaum, and Evans, 1999). It is difficult to isolate the effects of policy-induced changes in interest rates on monthly or quarterly macroeconomic variables from changes induced by other factors, however, and it is equally difficult to definitively differentiate the effects of monetary policy shocks from the effects of variables to which monetary policy reacts. That is, VAR

Brett Fawley is a quantitative analytics and reporting analyst at Rosen Consulting Group. Christopher J. Neely is an assistant vice president and economist at the Federal Reserve Bank of St. Louis. This article was written while Fawley was a senior research associate at the Federal Reserve Bank of St. Louis. The authors thank Rasmus Fatum, Ken Kuttner, Ed Nelson, Carlo Rosa, Juan Sánchez, Eric Swanson, and Dan Thornton for helpful comments and Sean Grover for research assistance.

○ 2014, The Federal Reserve Bank of St. Louis. The views expressed in this article are those of the author(s) and do not necessarily reflect the views of the Federal Reserve System, the Board of Governors, or the regional Federal Reserve Banks. Articles may be reprinted, reproduced, published, distributed, displayed, and transmitted in their entirety if copyright notice, author name(s), and full citation are included. Abstracts, synopses, and other derivative works may be made only with prior written permission of the Federal Reserve Bank of St. Louis. 


\section{Fawley and Neely}

analysis requires controversial identification assumptions to identify simultaneous causality because time aggregation of data to lower frequencies-such as the monthly or quarterly data used in VAR analysis-generally produces simultaneous causality in economic data even if there is unidirectional causality at very high frequencies. In other words, although it is unlikely that macro variables or asset price changes within the meeting day influence Federal Open Market Committee (FOMC) policy decisions, asset price changes in the weeks before such decisions very likely have influenced such decisions. The combination of simultaneity and the omission of many variables that affect asset prices inherently leave a great deal of uncertainty about the effect of monetary policy on monthly prices, output, and employment.

It is far easier to identify the effect of high-frequency (daily, hourly) monetary shocks on asset prices. If the monetary policy instrument and market expectations for its value are known, then it is possible to characterize the impact of monetary policy shocks-deviations from expectations-on asset prices, which react quickly to news and transmit monetary policy to the economy. Because financial markets are forward looking, one would normally expect asset prices to react only to the unexpected portion of monetary policy changes, as the expected portion would already be priced into assets. Such high-frequency studies of the effect of monetary shocks on asset prices interest both market participants and economists and constitute a useful first step to answering larger questions about the effects of monetary policy on macro variables.

Why study the effect of monetary policy shocks when systematic monetary policy presumably has greater total effects? Both systematic and unsystematic policy actions might be expected to affect asset prices. However, the effects of the systematic policy arise as new information (e.g., data releases, policy statements) becomes available and reshapes market expectations about the economy and the likely policy reaction. These expectations about economic conditions and the central bank's reaction function form over time and are influenced by both monetary and nonmonetary events. Therefore, it is very difficult to estimate the effects of these unobservable changes in expectations of systematic monetary policy on asset prices, though they will have an effect. In contrast, when a central bank makes a discrete change to policy, the monetary surprise changes expectations immediately-by definitionand it is easy to determine the effects of such surprises on asset prices, which inform us about the transmission of all monetary policy.

Such investigations have proliferated since the seminal work of Kuttner (2001), but efforts to draw those lessons together have been only limited and fragmented. This article remedies that deficiency by reviewing the literature that has sought to both characterize the response of asset prices to high-frequency monetary policy shocks and-more ambitiously—to explain those reactions. ${ }^{2}$

A central theme in this literature is that financial markets' expectations of monetary policy have become more accurate as Federal Reserve policy has become more transparent in its objectives and procedures. In the 1970s, the FOMC allowed inflation to rise to intolerable levels, which was symptomatic of the lack of clarity in the Fed's ultimate objectives. The fact that Cook and Hahn (1989) were able to link federal funds target changes-not just surprisesin the 1970s to asset price changes suggests that the Fed's lack of clarity produced such poor 
expectations of funds target changes that such changes were largely unexpected, nearly equivalent to surprises.

In 1979, however, the Federal Reserve's new Chairman, Paul Volcker, clarified that one of the Fed's long-run objectives was price stability, as he sought to dramatically reduce the inflation rate. By the late 1980s, the Fed had reestablished its commitment to price stability and was functionally again using the federal funds rate to achieve its objectives. ${ }^{3}$ As markets came to understand Fed objectives and its likely reactions, only the unexpected portion of federal funds target changes (the surprise) affected asset prices by the late 1980s (Kuttner, 2001). Researchers exploited a liquid federal funds futures market to accurately estimate market expectations and reduce the amount of measurement error in expectations (and, thus, surprises).

The Fed continued to become more transparent in its procedures in 1994-95 by greatly reducing unscheduled changes in the funds target, explicitly announcing the funds target at the conclusion of FOMC meetings, and describing the FOMC's view of economic conditions and monetary policy after each policy meeting. Each of these actions improved the market's ability to anticipate or react to Fed actions. Reducing intermeeting target changes made the timing of those changes easier to estimate and reduced the problem of omitted variables. ${ }^{4}$ Announcing the new target allowed market prices to reach the new target quickly. FOMC meeting statements allowed the FOMC to influence long rates by communicating its view of the economy and policy and presumably improved market forecasts of future policy (Poole, Rasche, and Thornton, 2002; Swanson, 2006). The influence of FOMC statements on the yield curve prompted Gürkaynak, Sack, and Swanson (2005) to develop a two-factor model of monetary policy shocks that has influenced further research.

In brief, researchers have found that federal funds rate surprises have consistent and sizable effects on other asset prices, including long-term interest rates, foreign exchange, and equities. For example, Kuttner (2001) estimates that a 100-basis-point surprise increase in the federal funds rate would raise 10 -year interest rates by about 30 basis points. Andersen et al. (2003) calculate that the same increase would raise the value of the dollar by 66 to 107 basis points, and Bernanke and Kuttner (2005) find that such a surprise would reduce equity prices by about 4 percent.

The rest of this article reviews the challenges involved in defining monetary policy shocks and accurately estimating their impact on asset prices.

\section{RESEARCH ON MONETARY POLICY SHOCKS AND ASSET PRICES}

The efficient markets hypothesis implies that, because financial markets are forward looking, only the unexpected portion of a monetary policy change should influence asset prices and it should do so very quickly (Fama, 1970). Therefore, any study of monetary policy must decompose actions into expected and unexpected portions; that decomposition depends on market perceptions of Federal Reserve objectives, procedures, and communications. A central theme of this article is that research on monetary policy shocks has evolved jointly with those FOMC objectives, procedures, and communications. As the Federal Reserve has become 


\section{Fawley and Neely}

more transparent in its objectives and communications, it has become better able to influence asset markets without disrupting them (Bernanke and Kuttner, 2005; Gürkaynak, Sack, and Swanson, 2005).

\section{Early Research on Effects of Monetary Shocks}

Any study of the effects of monetary policy must first define the monetary policy instrument, the primary tool that a central bank uses to influence the economy. Monetary instruments are closely related to, but distinct from, the stance of monetary policy-the contribution that monetary policy makes to economic and financial conditions-because any change in the instrument is likely to imply a change in the stance of monetary policy in the short run, though the stance can certainly change without a change in the instrument in the longer run. That is, researchers are interested in the monetary policy instrument because unexpected changes in the instrument equate to unexpected changes in the stance of monetary policy, though the stance of policy can change without a change in the instrument.

It is natural to think of monetary policy as operating through changes in measures of money and monetarists, such as Friedman, commonly characterized the stance of monetary policy with reference to the growth rate of money. ${ }^{5}$ Indeed, the Fed described its own policies in the 1970s and 1980s in terms of targeting various measures of reserves or monetary aggregates.

Thus, empirical studies of monetary policy during the 1970s and 1980s typically associated changes in monetary policy with changes in measures of the money supply. Sims (1980), for example, describes the monetarist view that "the time path of the money stock is a good single index of monetary policy." He questions the efficacy of monetary policy on the grounds that money adds no additional explanatory power to a system that includes output, prices, and a short interest rate.

The immediate predecessor of the literature examining high-frequency monetary policy shocks was the literature that searched for a liquidity effect: an injection of reserves that decreases the nominal interest rate. ${ }^{6} \mathrm{~A}$ large literature searched for this liquidity effect in various ways: estimating investment-savings, liquidity-preference-money-supply (IS-LM) models; regressing interest rates on functions of money growth; and studying asset price behavior around monetary stock announcements. The results were mixed, at best, with many studies finding negative or perverse results with aggregate data. Reichenstein (1987) surveys this literature and concludes that "the Fed appears to have little control over month-to-month changes in [short-term] interest rates." Despite the lack of clear success, researchers used VARs with aggregate data to continue to look for a liquidity effect well into the 1990s (Thornton, 2001b). The increasing adoption and recognition of overt interest rate targeting by central banks ultimately brought an end to this line of research, however (Friedman and Kuttner, 2011).

\section{Measuring Monetary Policy with the Federal Funds Rate}

Although the Federal Reserve described its policy objectives in the 1970s and much of the 1980 s in terms of targets for some measure of money or reserves, most central banks normally 
conduct monetary policy by trading short-term securities or managing short-term loans to banks to target a short-term interest rate. Observing that central banks usually conduct monetary policy through a short-term interest rate and that monetary aggregates do not predict output or interest rates very well, McCallum (1983) reasoned that if the Fed's behavior is determined by an interest rate rule, "policy innovations-i.e., the unsystematic portion of the Fed's behavior-are then represented as the stochastic disturbances appearing in this interest rate rule, not in some rule determining the value of the money stock."

Building on such observations, researchers began to equate the federal funds rate with the U.S. monetary policy instrument by the late 1980s. Cook and Hahn (1989) argue that, because the Fed uses the federal funds rate as its instrument and does not quickly reverse target changes, the funds rate should influence other interest rates. ${ }^{7}$ These authors regress changes in bill or bond rates on 75 federal funds target changes from September 1974 through September 1979, a period in which the Fed tightly controlled the funds rate:

$$
\Delta R_{t}=\beta_{1}+\beta_{2} \Delta R F F_{t}+u_{t},
$$

where $\Delta R_{t}$ is the change in a bond or bill rate and $\Delta R F F_{t}$ is the federal funds target change. Contrary to Reichenstein's (1987) conclusions surveying studies of the impact of money on interest rates, Cook and Hahn's results imply that a 1-percentage-point increase in the federal funds rate was associated with a 55-basis-point increase in 3-month Treasury bills and a 13basis-point increase in 10 -year bonds. ${ }^{8}$ Table 1 summarizes the empirical results from important papers in this literature while Table 2 describes their contributions.

Bernanke and Blinder (1992) implicitly support this use of the funds rate, arguing that the federal funds rate is "a good indicator of monetary policy" because it forecasts macro variables better than any other variables_-suggesting that it might affect these macro variables-and responds systematically to unemployment and inflation, which reflect the Fed's dual mandate. Furthermore, they argue that because the funds rate is insensitive to changes in demand for reserves, it "is mostly driven by policy decisions."

Some would criticize the use of regressions such as equation (1) to determine the effect of changes in the federal funds target on the grounds that the effect of the announcement change on asset prices is measured only over one day-or a few days-and might be temporary. Such criticisms are misplaced. Because uncertainty about asset prices usually rises with the forecast horizon, no one can know the long-term effects of any event on asset prices. The efficient markets hypothesis implies that the market's best guess must have been that the effects of the federal funds target change would persist. Otherwise, expectations of a temporary impact of a policy announcement would create a risk-arbitrage opportunity for investors to bet on the reversal of the policy's effects.

\section{The Importance of Expectations}

Studies on later samples failed to confirm the Cook and Hahn (1989) results, however. In particular, Radecki and Reinhart (1994) and Roley and Sellon (1995) failed to find any significant relationship between federal funds target changes and interest rates over later samples. ${ }^{9}$ 
Table 1

Estimated Impact of Monetary Policy Surprises on Interest Rates

\begin{tabular}{|c|c|c|c|c|c|c|c|c|c|}
\hline & $\begin{array}{c}\text { Kuttner } \\
(2001)\end{array}$ & $\begin{array}{c}\text { Poole and } \\
\text { Rasche (2000) }\end{array}$ & $\begin{array}{c}\text { Poole, } \\
\text { Rasche, and } \\
\text { Thornton (2002) }\end{array}$ & $\begin{array}{c}\text { Poole, } \\
\text { Rasche, and } \\
\text { Thornton (2002) }\end{array}$ & $\begin{array}{l}\text { Rigobon and } \\
\text { Sack (2004) }\end{array}$ & $\begin{array}{l}\text { Rigobon and } \\
\text { Sack (2004) }\end{array}$ & $\begin{array}{l}\text { Fleming and } \\
\text { Piazzesi (2005) }\end{array}$ & $\begin{array}{c}\text { Gürkaynak, } \\
\text { Sack, and } \\
\text { Swanson (2005) }\end{array}$ & $\begin{array}{l}\text { Hamilton } \\
(2008)\end{array}$ \\
\hline $\begin{array}{l}\text { Table number in } \\
\text { original article }\end{array}$ & Table 3 & Table 3 & Table 7 & Table 3 & Table 4 & Table 4 & Table 1 & Table 1 & Table 2 \\
\hline Sample & $\begin{array}{l}\text { 1989:06- } \\
2000: 02\end{array}$ & $\begin{array}{l}\text { 1988:10- } \\
\text { 2000:02 }\end{array}$ & $\begin{array}{c}\text { 1987:08- } \\
1993: 12\end{array}$ & $\begin{array}{l}\text { 1994:03- } \\
\text { 2001:05 }\end{array}$ & $\begin{array}{l}\text { 1994:01- } \\
\text { 2001:11 }\end{array}$ & $\begin{array}{l}\text { 1994:01- } \\
\text { 2001:11 }\end{array}$ & $\begin{array}{l}\text { 1994:01- } \\
\text { 2004:12 }\end{array}$ & $\begin{array}{l}\text { 1991:07- } \\
\text { 2004:12 }\end{array}$ & $\begin{array}{l}\text { 1998:10- } \\
\text { 2006:12 }\end{array}$ \\
\hline Observations & 42 & 53 & 38 & 62 & 73 & 73 & 93 & 120 & 4,552 \\
\hline Data frequency & Daily & Daily & Daily & Daily & Daily & Daily & 1-hour & 30-minute & Daily \\
\hline $\begin{array}{l}\text { Expectations } \\
\text { measure }\end{array}$ & $\begin{array}{l}\text { Current- } \\
\text { month FF }\end{array}$ & $\begin{array}{c}\text { Next- } \\
\text { month FF }\end{array}$ & $\begin{array}{l}\text { Next- } \\
\text { month FF }\end{array}$ & $\begin{array}{c}\text { Next- } \\
\text { month FF }\end{array}$ & $\begin{array}{l}\text { Current 3-month } \\
\text { eurodollar } \\
\text { future }\end{array}$ & $\begin{array}{l}\text { Current 3-month } \\
\text { eurodollar } \\
\text { future }\end{array}$ & $\begin{array}{l}\text { Current- } \\
\text { month FF }\end{array}$ & $\begin{array}{l}\text { Current- } \\
\text { month FF }\end{array}$ & $\begin{array}{l}\text { Current- } \\
\text { month FF }\end{array}$ \\
\hline $\begin{array}{l}\text { Expected and } \\
\text { surprise? }\end{array}$ & $\begin{array}{c}\text { With } \\
\text { anticipated }\end{array}$ & $\begin{array}{c}\text { With } \\
\text { anticipated }\end{array}$ & $\begin{array}{c}\text { With } \\
\text { anticipated }\end{array}$ & $\begin{array}{c}\text { With } \\
\text { anticipated }\end{array}$ & Surprise only & Surprise only & Surprise only & Surprise only & Surprise only \\
\hline
\end{tabular}

Correction? No correction No correction Errors-in-variables Errors-in-variables ID through ID through Intraday data Intraday data No correction correction correction heteroskedasticity heteroskedasticity

(IV) (GMM)

\section{Maturity of regressand}

\begin{tabular}{|c|c|c|c|c|c|c|c|c|c|}
\hline 3-month & $\begin{array}{c}79.1 \\
(9.4)\end{array}$ & $\begin{array}{l}73 \\
(9.0)\end{array}$ & $\begin{array}{c}82.3 \\
(10.0)\end{array}$ & $\begin{array}{c}80.8 \\
(28.0)\end{array}$ & & & $\begin{array}{c}66.6 \\
(4.4)\end{array}$ & $\begin{array}{l}53.7 \\
(4.0)\end{array}$ & $\begin{array}{c}65.8 \\
(2.2)\end{array}$ \\
\hline 6-month & $\begin{array}{c}71.6 \\
(8.4)\end{array}$ & & $\begin{array}{c}89.9 \\
(11.0)\end{array}$ & $\begin{array}{c}63.5 \\
(20.0)\end{array}$ & $\begin{array}{c}87.6 \\
(11.5)\end{array}$ & $\begin{array}{c}47.1 \\
(13.0)\end{array}$ & $\begin{array}{c}60.9 \\
(7.4)\end{array}$ & $\begin{array}{c}52.2 \\
(5.7)\end{array}$ & $\begin{array}{c}70.6 \\
(2.1)\end{array}$ \\
\hline 12-month & $\begin{array}{c}71.6 \\
(9.2)\end{array}$ & $\begin{array}{l}78 \\
(9.0)\end{array}$ & $\begin{array}{c}91.8 \\
(10.0)\end{array}$ & $\begin{array}{c}54.6 \\
(19.0)\end{array}$ & $\begin{array}{c}75.6 \\
(9.3)\end{array}$ & $\begin{array}{c}27.6 \\
(12.7)\end{array}$ & & & $\begin{array}{c}74.8 \\
(2.3)\end{array}$ \\
\hline 2-year & $\begin{array}{c}61.4 \\
(10.2)\end{array}$ & & $\begin{array}{c}76.1 \\
(14.0)\end{array}$ & $\begin{array}{c}36.4 \\
(20.0)\end{array}$ & $\begin{array}{l}79 \\
(11.2)\end{array}$ & $\begin{array}{c}15.5 \\
(11.6)\end{array}$ & $\begin{array}{c}48.3 \\
(13.0)\end{array}$ & $\begin{array}{c}45.5 \\
(8.7)\end{array}$ & $\begin{array}{c}68.5 \\
(2.9)\end{array}$ \\
\hline 3-year & & & & & & & & & $\begin{array}{c}64.1 \\
(3.0)\end{array}$ \\
\hline 5-year & $\begin{array}{c}48.1 \\
(11.2)\end{array}$ & & $\begin{array}{c}56.9 \\
(14.0)\end{array}$ & $\begin{array}{c}18.2 \\
(23.0)\end{array}$ & $\begin{array}{c}93 \\
(12.6)\end{array}$ & $\begin{array}{c}12.5 \\
(13.9)\end{array}$ & $\begin{array}{c}31.3 \\
(14.8)\end{array}$ & $\begin{array}{c}26.4 \\
(8.1)\end{array}$ & \\
\hline 10-year & $\begin{array}{c}31.5 \\
(10.2)\end{array}$ & $\begin{array}{l}48 \\
(10.0)\end{array}$ & $\begin{array}{c}42.6 \\
(11.0)\end{array}$ & $\begin{array}{c}2.7 \\
(22.0)\end{array}$ & $\begin{array}{c}61.1 \\
(13.7)\end{array}$ & $\begin{array}{c}0.8 \\
(10.2)\end{array}$ & $\begin{array}{c}8.3 \\
(15.6)\end{array}$ & $\begin{array}{c}12.5 \\
(5.8)\end{array}$ & $\begin{array}{c}42.6 \\
(2.8)\end{array}$ \\
\hline 30-year & $\begin{array}{l}19.4 \\
(8.4)\end{array}$ & & $\begin{array}{c}27.7 \\
(10.0)\end{array}$ & $\begin{array}{c}-7.5 \\
(13.0)\end{array}$ & $\begin{array}{c}35.2 \\
(13.6)\end{array}$ & $\begin{array}{r}-13.3 \\
(8.3)\end{array}$ & & & \\
\hline
\end{tabular}

NOTE: The lower half of the table displays regression coefficients (yield changes in basis points) and standard errors (in parentheses) from a number of articles on the impact of monetary policy (federal funds rate target) surprises on changes in interest rates of varying maturities. FF, federal funds target rate; GMM, generalized method of moments; ID, identification; IV, instrumental variables. 


\section{Table 2}

\section{Summary of the Most Important Papers in the Literature on Monetary Policy Surprises}

\section{Article}

Cook and Hahn (1989)

Kuttner (2001)

Poole, Rasche, and

Thornton (2002)

Rigobon and Sack (2004)

Correction for simultaneity/omitted variables

Bernanke and Kuttner

(2005)

Gürkaynak, Sack, and

Swanson (2005)

Fleming and Piazzesi (2005) Tick-by-tick analysis

Hamilton (2008)

Daily model with uncertainty over event days

Full sensitivity analysis for equities/Decomposition of equity return

wo-factor mode wo-factor model applied to full set of international assets

\section{Method/Innovation}

Results

"We find that changes in the target caused large movements in short-term rates and smaller but significant movements in intermediate- and long-term rates."

"Interest rates' response to anticipated target rate changes is small, while their response to unanticipated changes is large and highly significant."

"The estimates...suggest that Treasury rates respond significantly to unexpected changes in the Fed's funds rate target...[T]he response of the Treasury rate to unexpected target changes declines as the term lengthens...We find that the response of the 3-month T-bill rate is nearly identical before and after [the 1994] procedural change. The magnitude and significance of the response of longer-term rates, however, declines after this procedural change."

"The results indicate that an increase in short-term interest rates results in a decline in stock prices and in an upward shift in the yield curve that becomes smaller at longer maturities. The findings also suggest that the event-study estimates contain biases that make the estimated effects on stock prices appear too small and those on Treasury yields too large."

"We find that, on average, a hypothetical unanticipated 25-basis-point cut in the Federal funds rate target is associated with about a $1 \%$ increase in broad stock indexes. Adapting a methodology due to Campbell and Ammer, we find that the effects of unanticipated monetary policy actions on expected excess returns account for the largest part of the response of stock prices."

"We test whether [monetary policy] effects are adequately captured by a single factorchanges in the federal funds rate target-and find that they are not. Instead, we find that two factors are required. These factors have a structural interpretation as a 'current federal funds rate target' factor and a 'future path of policy' factor, with the latter closely associated with Federal Open Market Committee statements...According to our estimates, both monetary policy actions and statements have important but differing effects on asset prices, with statements having a much greater impact on longer-term Treasury yields."

"Analysis of high-frequency data shows that Treasury note yields are highly volatile around FOMC announcements, even though the average effects of fed funds target rate surprises on such yields are fairly modest."

"This paper develops a generalization of the formulas proposed by Kuttner (2001) and others for purposes of measuring the effects of a change in the federal funds target on Treasury yields of different maturities...Although the methods are new, the conclusion is quite similar to that reported by earlier researchers - changes in the fed funds target seem to be associated with quite large changes in Treasury yields, even for maturities of up to 10 years."

"This paper analyzes the impact of U.S. monetary policy announcement surprises on foreign equity indexes, short- and long-term interest rates, and exchange rates in 49 countries...

Global equity indexes respond mainly to the target surprise; exchange rates and long-term interest rates respond mainly to the path surprise; and short-term interest rates respond to both surprises. 


\section{Fawley and Neely}

Thornton (1998) criticizes Cook and Hahn's target change series as being endogenousthat is, partially expected and therefore not true policy surprises. Likewise, Kuttner (2001) argues that the failure to confirm Cook and Hahn's results on later samples is due to the failure to decompose monetary policy shocks into their expected and surprise components. ${ }^{10}$ Expected funds rate changes should not influence other asset prices because financial markets are forward looking; only the unexpected component of changes in the federal funds target should change other asset prices. ${ }^{11}$ In the 1970s, funds rate expectations were apparently so poor that changes in the funds target were good proxies for their unexpected component. By the late 1980s, however, clearer Fed objectives and procedures allowed markets to anticipate a large portion of federal funds target changes, so changes in the funds target became poor proxies for their unexpected component. Therefore, researchers began to consider how to decompose federal funds rate changes into expected and unexpected components to test the effect of the latter with high-frequency data.

The most common method to compute expectations of the federal funds target is due to Kuttner (2001), who used prices from the federal funds futures market. The basic idea is that the futures market implies an average federal funds rate for a particular contract month andbecause the New York Open Market Desk can keep the average federal funds rate near the target-this implies an average federal funds target for the contract month. Thus, the market's expectation of the change in the target on the FOMC meeting date can be calculated if the target at the start of the month and the date on which the target might be changed are known. Appendix A on the federal funds futures market details this procedure.

Using these procedures to decompose the surprise and expected components of federal funds target changes from June 1989 to February 2000, Kuttner (2001) estimates

$$
\Delta R_{t}^{n}=\alpha+\beta_{1} \Delta \tilde{r}_{t}^{e}+\beta_{2} \Delta \tilde{r}_{t}^{u}+\varepsilon_{t}
$$

where $\Delta R_{t}^{n}$ is the change in the yield of an $n$-year Treasury bond on date $t$, and $\Delta \tilde{r}_{t}^{e}$ and $\Delta \tilde{r}_{t}^{u}$ are the expected and surprise components of the federal funds target change on day $t$. Using 42 days of changes in the FOMC target, Kuttner finds that an unexpected 1-percentage-point increase in the federal funds target raises 3 -month Treasury yields by 79 basis points and 10year yields by 32 basis points. The reaction to the surprise component is significant at all maturities analyzed, while the impact of expected changes is always small and insignificant. Table 3 illustrates Kuttner's results on the set of all FOMC events (all FOMC meetings plus intermeeting rate changes) from October 1988 to June 2007. Some anticipated target changes are statistically significant at the very short end of the yield curve, presumably because the central bank can control the very short end of the yield curve through the open market operations that pin down the federal funds rate. The unanticipated component, however, clearly has the much stronger and more statistically significant impact on interest rates at all horizons.

Kuttner (2001) claims that federal funds futures offer three advantages over other procedures to identify expectations of monetary policy: (i) Futures require no model; (ii) futures data are not revised and so there is no "data vintage" problem; and (iii) futures do not entail an errors-in-variables problem as do VARs. ${ }^{12}$ In addition, Gürkaynak, Sack, and Swanson 


\section{Table 3}

\section{Response of Interest Rates to Expected and Unexpected Components of Federal Funds Target Surprises (1988-2007)}

\begin{tabular}{lcccc} 
Maturity & Intercept & Anticipated & Unanticipated & $R^{2}$ \\
\hline 3-month & -0.01 & 0.05 & 0.66 & 0.60 \\
& $(-3.7)$ & $(2.2)$ & $(15.2)$ & 0.58 \\
6-month & -0.02 & 0.05 & 0.64 & 0.53 \\
& $(-3.8)$ & $(2.3)$ & $(14.5)$ & 0.62 \\
12-month & -0.01 & 0.03 & $(13.3)$ & 0.30 \\
& $(-1.9)$ & $(1.5)$ & 0.46 & 0.15 \\
2-year & -0.01 & 0.05 & $(8.1)$ & 0.32 \\
5-year & $(-1.1)$ & $(1.7)$ & $(5.2)$ & 0.06 \\
& 0.00 & 0.02 & 0.17 & 0.02 \\
10-year & $(-0.8)$ & $(0.7)$ & $(3.2)$ & 0.08 \\
30-year & 0.00 & -0.01 & $(1.9)$ & 0.02 \\
& $(-0.5)$ & $(-0.2)$ & &
\end{tabular}

NOTE: The table shows the results of a regression similar to that of Kuttner (2001, equation (2)) that uses all FOMC events from October 1988 to June 2007. The event set includes 177 events, including all regularly scheduled FOMC meetings, plus intermeeting rate changes. Shaded numbers denote significantly positive (blue) or negative (red) $t$-statistics.

(2007) show that federal funds futures are the best-available forecasts of federal funds targets at horizons of up to 6 months. ${ }^{13}$ These advantages have made federal funds futures the standard metric for computing expectations of the federal funds target.

The most attractive alternative to using federal funds futures data to calculate expectations for the federal funds target is to use some sort of survey data. Andersen et al. (2003), for example, use Money Market Services (MMS) survey data in their broad study of the effects of macro announcements on foreign exchange returns and volatility. Using data from January 1992 to December 1998, they find that positive funds target surprises significantly appreciate the dollar for four of the five exchange rates.

The use of expectations from the federal funds futures market, rather than from MMS survey data, implies similar effects of funds target surprises on the foreign exchange market. Fatum and Scholnick (2006) determine that changes in 2-month-ahead federal funds futures on days without monetary policy news, which the authors interpret as policy expectations, are significant predictors of three exchange rates at the daily frequency and the response is rapid, within the day. Faust et al. (2007) find somewhat larger results with FOMC meetingday data from March 1995 through December 2002 and expectations from the federal funds futures market. Their regressions using 20-minute windows imply that a 100-basis-point surprise increase in the funds target would depreciate the dollar 123 basis points against the deutsche mark/euro (DEM/EUR) and 66 basis points against the British pound (GBP). The impacts are highly statistically significant. 


\section{Noisy Measures of Monetary Policy}

Computing shocks to the federal funds target entails confronting the fact that expectations of the federal funds target - and therefore the surprises in the federal funds target-are measured with some error because of bid-ask spreads, stale expectations, and risk premia. ${ }^{14}$ When regressors are measured with error, the coefficients on those regressors are biased and the expected values are attenuated toward zero. Poole, Rasche, and Thornton (2002) correct for such errors-in-variables bias by estimating the size of the measurement error from policy actions that were correctly anticipated. The authors gauge the degree of correct anticipation from surveys and commentary in the "Credit Markets" section of the Wall Street Journal published on the days before FOMC meetings. Using this correction and with data from March 1994 through May 2001, the authors report that a 1-percentage-point reduction in the federal funds target reduces 3 -month Treasury yields by 77 to 82 basis points and 10-year Treasury yields from 40 to 43 basis points. The corrected estimates are somewhat larger than (but fairly close to) the uncorrected estimates, indicating that measurement error is not a major problem. ${ }^{15}$

Hamilton (2008) develops a method to measure monetary policy surprises to account for both noise induced by deviations in the effective federal funds rate from its target and uncertainty about the date of policy actions (as may have been important prior to 1994). ${ }^{16}$ The method extracts the monetary policy signal from daily federal funds futures changes under the assumption that the econometrician does not know the dates of policy actions and must take them to be equally likely on all dates in the sample. Using this procedure, Hamilton (2008) estimates his regression over all business days, not just those with FOMC meetings or known target changes, to find that a 1-percentage-point surprise to the federal funds target increases 3 -month Treasury yields by 66 basis points and 10 -year yields by 43 basis points.

\section{Simultaneity and Omitted Variables in Asset Price Reactions to Monetary Policy}

If nonmonetary news influences monetary policy and asset prices within the event window, or if monetary policy responds contemporaneously to asset price changes within the event window, then that complicates the study of monetary policy's effect on asset prices. The first problem is omitted variables bias, while the second problem is simultaneity bias. ${ }^{17}$ Appendix B describes these problems in some detail. In either case, a naive event study estimate of the impact of target rate changes on asset prices will inconsistently estimate the true impact of those target rate changes. To understand these biases, consider a linear system in which monetary policy $\left(\Delta m_{t}\right)$ and asset prices $\left(\Delta p_{t}\right)$ are determined simultaneously as follows:

$$
\Delta p_{t}=a_{0}+a_{1} \Delta m_{t}+a_{2} n e w s_{t}+e_{p, t}
$$

$$
\Delta m_{t}=b_{0}+b_{1} \Delta p_{t}+b_{2} n e w s_{t}+e_{m, t},
$$

where news ${ }_{t}$ denotes macro releases that potentially affect monetary policy and asset prices. 
Omitted variables bias occurs when nonmonetary news within the event window moves financial prices but the nonmonetary regressor is incorrectly excluded. That is, $a_{2} \neq 0$ but the estimated regression imposes $a_{2}=0$. In that case, the event study estimate of the impact of target rate changes will be biased.

If monetary policy reacts to asset price changes within the observation interval for the data-for example, within the day for daily data-then $b_{1}$ will be nonzero in equation (4) and an ordinary least squares (OLS) estimate of $a_{1}$-the effect of the monetary policy change on the asset price-will be inconsistent. As the observation interval around a policy change becomes arbitrarily small, the parameter $b_{1}$ will tend to go to zero-equation (4) will contain only lagged values of $\Delta p_{t}$, which present no simultaneity problem-and the OLS estimator of $a_{1}$ becomes consistent.

Although the FOMC rarely directly reacts to asset price changes within a day-that is, it seems likely that $b_{1}=0$ but there are lags of $\Delta p_{t}$ in equation (4)-it is more plausible that omitted variables bias presents a problem. Specifically, prior to February 1994, Chairman Alan Greenspan changed the federal funds target on several days of weak employment reports, presumably in response to those releases (i.e., $a_{2} \neq 0$ in equation (3)). ${ }^{18} \mathrm{~A}$ negative employment report will tend to directly reduce equity prices and interest rates, but it will also tend to make the FOMC reduce interest rates, which will tend to increase equity prices but reduce longerterm interest rates. If the whole effect were naively ascribed to the policy shock-ignoring possible joint-response bias - then equity responses would be underestimated and yield responses to policy shocks would be overestimated. Bernanke and Kuttner (2005) report that failing to account for the omitted variables bias related to target changes that occur on the same day as employment reports attenuates the average stock market response in their sample by 1 percentage point.

To address these occasions when policy surprises react to asset price changes or (much more frequently) react to other news, researchers have sought to identify the effects of monetary policy shocks with (i) explicit identification schemes with daily data or (ii) higher-frequency data and narrow event windows. ${ }^{19}$

Rigobon and Sack (2004) pursue the first strategy: These authors identify monetary shocks from FOMC meetings and the semiannual monetary policy testimony from the daily conditional heteroskedasticity of nearby futures on 3-month eurodollar interest rates over a sample from 1994 through November 2001. The nearby futures on 3-month interest rate contracts are used to reduce problems with timing issues (as discussed more extensively in the following subsections). These authors exploit the fact that policy shocks display greater variance on announcement days than nonannouncement days to identify the effect of monetary policy shocks, solving the usual problems of simultaneity/omitted variables in daily interest rate data in a way that does not require the strong assumptions of daily event studies. ${ }^{20}$

The two heteroskedasticity estimators employed by Rigobon and Sack (2004) diverge widely in the degree to which they indicate that event studies overstate yield responses. Rigobon and Sack (2004) find that a 1-percentage-point surprise federal funds target cut (i) increases broad stock indexes by 4.85 to 10.06 percentage points and (ii) lowers 6-month Treasury yields by 47 to 88 basis points and 10-year Treasury yields by 1 to 61 basis points. The authors attrib- 


\section{Fawley and Neely}

ute the large effects on stock prices to the lack of downward bias in their estimates compared with event study estimates, but they also report that using federal funds futures instead of futures on 3-month eurodollars produces smaller estimates of the impact of monetary shocks.

Rosa (2011b) reexamines the biases that Rigobon and Sack's (2004) identification-throughheteroskedasticity methods are designed to confront. Rosa (2011b) finds a small but statistically significant bias in event study estimates of asset market reactions. Nevertheless, Rosa recommends the event study estimator because its bias is small and it outperforms the heteroskedasticity-based estimator.

The second strategy to avoid omitted variables and/or simultaneity is to use highfrequency (intraday) data to estimate the effect of monetary policy on asset prices $\left(a_{1}\right)$. At a sufficiently high frequency, asset prices presumably have no effect on monetary policy $\left(b_{1}=0\right)$ and even news variables are predetermined, so the relation can be simply estimated by OLS. Gürkaynak, Sack, and Swanson (2005) and Fleming and Piazzesi (2005) use intraday data from 1994 through 2004 and 30-minute event windows to estimate the effects of policy surprises on yield changes. The Fleming and Piazzesi (2005) results generally confirm those from daily event studies: A 1-percentage-point cut in the federal funds target lowers 3-month Treasury yields by 67 basis points and 10-year Treasury yields by 8.3 basis points (although the latter response is insignificant). ${ }^{21}$

\section{Federal Funds Surprises and Equity Prices}

A large literature debates the extent to which monetary policy affects the economy through interest rate channels and/or credit channels. Monetary policy can affect consumption, investment, and the international competitiveness of domestic goods by influencing the foreign exchange value of the domestic currency and stock prices. Credit channels exploit the fact that easier monetary policy can improve consumers' and firms' balance sheets and thus reduce the effect of certain financial frictions-adverse selection and moral hazard-that hinder borrowing (Mishkin, 1995). ${ }^{22}$ Thus, monetary policy is often thought to generate a substantial portion of its effects through equity markets. Therefore, economists study how much and why monetary surprises affect stock prices and what these answers imply for monetary policy channels.

To answer these questions, Bernanke and Kuttner (2005) studied monetary policy effects on equity prices using data from May 1989 through December 2002. This study carefully considered factors that could affect the response, such as distinguishing scheduled from unscheduled target changes, simultaneity between news and target changes, and the timing of target changes - an advancement or postponement of an expected action-or whether they signal persistent changes in interest rates. Positive (negative) federal funds target shocks significantly reduced (raised) equity prices; high-tech sectors reacted more strongly than did broad indexes. The authors found no evidence for asymmetry in the magnitude of positive/negative target shocks, but they did find that reversals - for example, a target increase after a series of decreaseshad particularly strong effects on equities, although they cautioned there are only five such observations in the sample. The authors also showed that six "outliers" - four of which are intermeeting moves-strongly influenced the estimated impact coefficients. The authors speculated 
that these very strong effects were due to the fact that intermeeting moves convey much more urgency than equally sized surprises at regularly scheduled FOMC meetings.

Perhaps the main contribution of Bernanke and Kuttner (2005), however, is their use of federal funds surprises, measured with futures data, to study the source of the equity returns with a Campbell and Shiller (1988) decomposition of excess equity returns into expectations of future dividends, interest rates, and excess returns. ${ }^{23}$ This methodology implies that positive federal funds surprises reduce expected excess returns or dividends-depending on the sample-but not real interest rates. The authors interpret an effect on expected excess returns as arising from an increase in the riskiness of stocks or the willingness of investors to bear stock risk. Alternatively, the change in expected excess returns might stem from overreaction or excess sensitivity to policy.

The aggregated equity returns used by Bernanke and Kuttner (2005) cannot shed much light on differential responses by individual stocks and industry portfolios to monetary policy surprises. To investigate such heterogeneity, Ehrmann and Fratzscher (2004) regress daily returns for individual U.S. firms and industry portfolios on monetary policy surprises from 79 FOMC meetings from 1994 through January 2003. The expectations are computed using Reuters' surveys of market participants. The results have mixed implications for the credit and interest rate channels, however. The fact that stock prices of financially constrained firms react strongly to monetary policy tends to support the credit channel, while the strong reaction of firms in cyclical and capital-intensive industries tends to support the interest rate channel. Basistha and Kurov (2008) investigate the reactions of individual stocks to find that all stocks tend to react particularly strongly to monetary policy in recessions and tight credit conditions. Stock prices of financially constrained firms display particularly strong asymmetry, however, which the authors interpret as further evidence for the credit channel.

Two papers extend this research to investigate the impact of U.S. funds target surprises on international equity prices. Ehrmann and Fratzscher (2009) consider how national characteristics-openness, exchange rate regime, and so on-determine the strength of the transmission process. On average, a 100-basis-point surprise U.S. tightening reduces equity prices by 2.7 percent, although there is a great deal of heterogeneity in responses to U.S. monetary policy surprises, both across countries and across sectors. Financially open and more integrated countries have stronger equity market reactions. The reaction of U.S. short-term interest rates to the target surprise appears to govern the strength of the overall transmission to foreign equities, and countries with strong equity market reactions to U.S. target surprises also tend to exhibit strong exchange rate and interest rate reactions.

Ammer, Vega, and Wongswan (2010) examine the impact of U.S. target surprises on firmlevel equities from the United States and 21 foreign countries. ${ }^{24}$ Consistent with Bernanke and Kuttner's (2005) results for U.S. equities, they find that an unexpected tightening of 100 basis points reduces U.S. and foreign equity prices by 6.4 percent and 6.8 percent, respectively. The authors interpret the sensitivity of cyclical industries as supporting the demand (interest rate) channel of monetary policy. In contrast to the Ehrmann and Fratzscher (2009) results, Ammer, Vega, and Wongswan (2010) find that countries with fixed exchange rates respond more strongly to U.S. target surprises than do countries with flexible exchange rates. 


\section{Increasing Predictability in Fed Policy}

In 1994, the FOMC greatly reduced the frequency of intermeeting funds target changes and began to issue statements after policy meetings. Such statements could potentially contain three distinct pieces of information: (i) the current policy action in terms of the federal funds target or asset purchases; (ii) a statement on current or future economic conditions; and (iii) a forecast for the path of policy. ${ }^{25}$ Table 4, excerpted from Middeldorp (2011), describes changes in FOMC communication policy from 1993 to 2007.

The information in the announcements was initially very simple-a qualitative description of the change in the funds target:

Chairman Alan Greenspan announced today that the Federal Open Market Committee decided to increase slightly the degree of pressure on reserve positions. The action is expected to be associated with a small increase in short-term money market interest rates. (FOMC, 1994a)

Such postmeeting statements later became more elaborate, with numerical changes to the target and brief discussions of economic conditions, as in this excerpt from the August 1994 FOMC press release (FOMC, 1994b):

The Federal Reserve announced today the following monetary policy actions:

- The Board of Governors approved an increase in the discount rate from 31/2 percent to 4 percent, effective immediately.

- The Federal Open Market Committee agreed that this increase would be allowed to show through completely into interest rates in reserve markets.

These measures were taken against the background of evidence of continuing strength in the economic expansion and high levels of resource utilization. The actions are intended to keep inflationary pressures contained, and thereby foster sustainable economic growth.

The practices of reducing the frequency of intermeeting target changes and issuing statements allowed markets to better anticipate the timing and direction of policy target changes (see the boxed insert). In the pre-February 1994 sample, Poole, Rasche, and Thornton (2002) "find few instances where there was a widespread expectation that the Fed would take an action on a particular day." In contrast, Poole, Rasche, and Thornton (2002) identify only 18 "surprise" events in the set of 62 policy events from March 1994 to May 2001, using articles from the Wall Street Journal to assess expectations. Swanson (2006) demonstrates that the private sector has become better at forecasting interest rates and less surprised by Fed actions since the late 1980s. He attributes this improvement to increased Fed transparency, showing as a control that GDP and inflation forecasts did not improve over the same period. These factors reduced the measured effects of policy surprises on longer-term interest rates (Poole and Rasche, 2000; Poole, Rasche, and Thornton, 2002). For example, compare the decline in coefficients in the "Target" columns from the first to the second panel in Table $5 .{ }^{26}$

\section{Multidimensionality: Two Monetary Policy Factors}

The increasing predictability of Fed policy, as documented by Swanson (2006), might well be partly due to the FOMC's strategy of releasing statements regarding the economic outlook 


\section{Table 4}

\begin{tabular}{|c|c|c|}
\hline Date & Label & Nature of change \\
\hline March 1993 & Minutes & $\begin{array}{l}\text { Merging of FOMC "Minutes of Actions" and "Policy Record" into one new } \\
\text { document labeled the "Minutes of the FOMC" }\end{array}$ \\
\hline February 1994 & Statement & First postmeeting statement with qualitative description of change in policy \\
\hline August 1994 & Rationale & Some reasoning behind the decision is added to the statement \\
\hline July 1995 & Federal funds target & Inclusion of actual numerical federal funds target in statement \\
\hline May 1999 & Bias & Inclusion of FOMC's asymmetric policy directive in statement \\
\hline January 2000 & Balance of risks & $\begin{array}{l}\text { Revised statement language discussing balance of risks toward growth or } \\
\text { inflation rather than bias for federal funds target }\end{array}$ \\
\hline March 2002 & FOMC vote & Inclusion of vote with name(s) of dissenters in statement \\
\hline August 2003 & Guidance & $\begin{array}{l}\text { Statement language explicitly indicating the likely direction of rates over } \\
\text { extended period }\end{array}$ \\
\hline January 2005 & Earlier minutes & Minutes released three weeks after meeting \\
\hline November 2007 & Enhanced projections & More detailed, frequent, and extended projections \\
\hline
\end{tabular}

and likely future policy after its meetings. This suggests that the FOMC might be able to influence the whole yield curve-not just the very short end-by communicating its intentions to markets. The reason for this is that long-term interest rates depend, in part, on the expected path of future short-term interest rates, which the FOMC can influence.

Fleming and Piazzesi (2005) and Gürkaynak, Sack, and Swanson (2005) identify specific cases where the response of long rates appears to be unrelated to the measured surprise to the funds target. Specifically, Gürkaynak, Sack, and Swanson (2005) identify large responses in 2 - to 5-year Treasury yields after the January 28, 2004, policy meeting, despite the fact that there was almost no surprise in the federal funds target. The authors attribute these unusual responses to changes in expectations shaped by the FOMC's meeting statements rather than the policy action itself. The independence of long rate changes and federal funds surprises motivates Gürkaynak, Sack, and Swanson (2005) to develop a two-factor model of monetary policy shocks (see Appendix C). ${ }^{27} \mathrm{~A}$ single factor fails to adequately describe yield curve reactions (up to one year ahead) to monetary policy shocks, but statistical tests cannot reject the same null of two factors for yields up to a year. The first factor (target or timing) is closely related to current-month federal funds futures surprises, while the second factor (level or path) correlates strongly with 1-year eurodollar futures (i.e., 1-year-ahead policy expectations).

The second factor significantly increases the power of monetary policy actions to explain medium- to long-term interest rate changes, with the largest improvements at the longest maturities: The 10-year yields respond almost three times more to the path factor than the target factor, and the $R$-squared rises from 8 percent to 74 percent (Gürkaynak, Sack, and Swanson, 2005). The path factor is less important for equity returns, however: The coefficient 


\section{Fawley and Neely}

\section{The Evolution of Fed Policy}

One needs to define a monetary policy instrument to study the effects of monetary policy surprises on asset prices. The nature of Federal Reserve monetary policy has changed over time, however, from a hybrid of interest rate targeting to hit ranges for monetary aggregates, to targeting for various categories of bank reserves, and back to explicit interest rate targeting. This evolution of Fed policy can be interpreted as a series of moves toward greater transparency in objectives and procedures that have strongly influenced the methods and assumptions of monetary policy researchers, as well as the impact of monetary policy on asset prices.

From 1970 to October 1979, the Federal Reserve targeted growth rates for monetary aggregates, primarily M1 but also M2 (Meulendyke, 1998). The Full Employment and Balanced Growth Act of 1978 (the Humphrey-Hawkins Act) enshrined monetary targeting into law by requiring the Federal Reserve to set targets for calendar years and to explain any deviations. To realize these money supply growth targets, the FOMC chose a target for the federal funds rate and instructed the New York Fed Trading Desk to trade appropriately to correct deviations of the funds rate from this target. Gradually, the Desk began to control the federal funds rate fairly closely (Meulendyke, 1998).

Unfortunately, Federal Reserve monetary policy in the 1970s failed to control inflation. ${ }^{1}$ Annual consumer price index inflation reached 12.2 percent per year in September 1979, eventually peaking at 14.8 percent per year in March 1980. Many analysts blamed federal funds rate targeting for producing too much inertia in policy (Meulendyke, 1998). As a result, in October 1979, Chairman Volcker announced that the FOMC would target nonborrowed reserves, rather than the funds rate, to achieve desired M1 growth.

In 1983, the lack of a stable relation between M1 growth and economic activity led the FOMC to change procedures again, this time to targeting borrowed reserves (total reserves less nonborrowed reserves). ${ }^{2}$ In practice, analysts interpreted this procedure as a move back toward "soft" interest rate targeting (Thornton, 1988). This procedure, however, depended on a stable function for bank borrowing from the Fed. Banking problems - particularly those of Continental Illinois in 1984-soon led banks to become very wary of borrowing from the Federal Reserve, lest investors, depositors, and/or regulators conclude they were in financial trouble (Meulendyke, 1998). As with M1 targeting, the policy of targeting borrowed reserves failed because the borrowing function was unstable; banks became less willing to borrow from the Fed and borrowed reserves were not closely related to prices or economic activity (Thornton, 1988).

\footnotetext{
${ }^{1}$ Researchers broadly agree that changing ideas on the objectives and scope of monetary policy were critical to the development of the Great Inflation and the subsequent Great Disinflation, but they disagree about why the Fed failed to act. DeLong (1997) believes that the Great Depression left the Federal Reserve with no mandate to control inflation at the expense of unemployment. In contrast, Romer and Romer (2002) implicitly argue that the Fed used a fairly sophisticated but deeply flawed model that claimed to offer an exploitable inflation-unemployment trade-off. Nelson $(2005 a, b)$ and Nelson and Nikolov (2004) argue that "monetary neglect" - emphasis on nonmonetary factors in inflation-largely explains the Great Inflation not only in the United States but also in Canada, Australia, New Zealand, and the United Kingdom.

2 Banks can borrow reserves directly from the Fed through the discount window to meet reserve requirements, avoid overnight overdrafts, or meet seasonal funding needs. The demand for borrowed reserves theoretically reflects the tightness of credit conditions in the nonborrowed reserves market.
} 


\section{The Evolution of Fed Policy (cont'd)}

By the late 1980s, the FOMC was effectively targeting the federal funds rate, although it did not announce changes in the federal funds target immediately after FOMC meetings. Instead, markets had to infer new targets from the Desk's trading patterns, which could take a day or two. In addition, during the late 1980s and early 1990s, the FOMC's standard practice was to change the funds target between scheduled meetings, often in response to incoming economic news.

In 1994, the FOMC changed its procedures in three ways. First, the FOMC began publicly announcing changes to the target immediately after the meeting or decision. Second, the FOMC almost eliminated intermeeting target changes, which had been common in prior years. ${ }^{3}$ From October 1988 to December 1993, the FOMC changed the federal funds target 32 times, but only 9 times at a scheduled meeting. From 1994 to 2012, the FOMC has changed the target 60 times, 53 of which were at a scheduled meeting. ${ }^{4}$ Third, the FOMC began to issue statements on the state of the economy and monetary policy immediately after meetings. The statements initially were short and qualitatively described the federal funds target policy but became more detailed in August 1994 and included a numerical description of the funds target by July 1995.

FOMC communication policy continued to evolve. In May 1999, the FOMC began to issue a statement of its "bias," or the direction in which its next move was most likely. But this approach was replaced by a "balance of risks" statement in January 2000 that switched the statement's emphasis to the likely risks to growth or inflation. From August 2003 to December 2005, the FOMC added implicit forward guidance about the likely future course of the funds target. This practice began again in December 2008 in the wake of the financial crisis.

Of course, the financial crisis in the summer and fall of 2008 also motivated the FOMC to institute many temporary special programs to support credit markets and to announce the first of several asset purchase programs in November 2008.

${ }^{3}$ The FOMC had been reducing the frequency of intermeeting target changes prior to February 1994 . The seven intermeeting target changes since 1994 occurred on 4/18/1994, 10/15/1998, 1/3/2001, 4/18/2001, 9/17/2001, 1/22/2008, and 10/8/2008. The 10/15/1998 target change came on the heels of the Long-Term Capital Management collapse, which had been affected by the Russian default (8/17/1998); and the 9/17/2001 change followed the 9/11 terrorist attacks.

${ }^{4}$ FOMC transcripts reveal that Chairman Greenspan came to consider the practice of making decisions only at scheduled meetings to be a "very useful procedure." The Chairman would sometimes hint at policy decisions between meetings, however (FOMC, 1998). The FOMC has also changed the federal funds target much less frequently since 1994. The FOMC did not begin making target changes in multiples of 25 basis points until late 1989; previously, changes in multiples smaller than 25 basis points were common (Poole, Rasche, and Thornton, 2002).

on the target factor is four times that of the path factor in a regression of the Standard and Poor's (S\&P) 500 index returns on the two factors, and the $R$-squared improves little.

Table 5 shows results of an exercise similar to that in Gürkaynak, Sack, and Swanson (2005), in which one regresses daily interest rate changes on target and path factors, plus a constant (coefficient not shown). The top panel shows the results for all FOMC meetings; the bottom panel shows the results with employment reports removed. The target coefficients in the 1988-93 subsample are uniformly larger than those in the 1994-2007 subsample, particularly at longer horizons, and tend to be more statistically significant despite the shorter sample. At the same time, the coefficients on the path factor become larger and more statistically significant in the second subsample. This pattern presumably occurs because the introduc- 


\section{Fawley and Neely}

Table 5

Response of Interest Rates to Target and Path Shocks

\begin{tabular}{|c|c|c|c|c|c|c|c|c|c|}
\hline & \multicolumn{3}{|c|}{$1988-93$} & \multicolumn{3}{|c|}{ 1994-2007 } & \multicolumn{3}{|c|}{ 1988-2007 } \\
\hline & Target & Path & $R^{2}$ & Target & Path & $R^{2}$ & Target & Path & $R^{2}$ \\
\hline \multicolumn{10}{|c|}{ All meeting observations } \\
\hline 3-month & $\begin{array}{r}0.94 \\
(14.9)\end{array}$ & $\begin{array}{r}0.18 \\
(3.3)\end{array}$ & 0.79 & $\begin{array}{r}0.63 \\
(12.3)\end{array}$ & $\begin{array}{r}0.35 \\
(7.7)\end{array}$ & 0.66 & $\begin{array}{r}0.74 \\
(20.1)\end{array}$ & $\begin{array}{c}0.18 \\
(8.5)\end{array}$ & 0.73 \\
\hline 6-month & $\begin{array}{r}0.98 \\
(14.5)\end{array}$ & $\begin{array}{c}0.17 \\
(2.8)\end{array}$ & 0.78 & $\begin{array}{r}0.58 \\
(16.1)\end{array}$ & $\begin{array}{r}0.48 \\
(15.1)\end{array}$ & 0.82 & $\begin{array}{r}0.73 \\
(23.4)\end{array}$ & $\begin{array}{r}0.24 \\
(13.4)\end{array}$ & 0.81 \\
\hline 12-month & $\begin{array}{r}1.07 \\
(22.8)\end{array}$ & $\begin{array}{c}0.14 \\
(3.4)\end{array}$ & 0.90 & $\begin{array}{r}0.47 \\
(14.7)\end{array}$ & $\begin{array}{r}0.56 \\
(19.9)\end{array}$ & 0.85 & $\begin{array}{r}0.69 \\
(27.2)\end{array}$ & $\begin{array}{r}0.31 \\
(20.8)\end{array}$ & 0.87 \\
\hline 2-year & $\begin{array}{r}1.00 \\
(22.4)\end{array}$ & $\begin{array}{c}0.10 \\
(2.4)\end{array}$ & 0.89 & $\begin{array}{c}0.27 \\
(8.3)\end{array}$ & $\begin{array}{r}0.73 \\
(25.5)\end{array}$ & 0.87 & $\begin{array}{r}0.52 \\
(20.8)\end{array}$ & $\begin{array}{r}0.41 \\
(28.2)\end{array}$ & 0.88 \\
\hline 5-year & $\begin{array}{r}0.86 \\
(13.5)\end{array}$ & $\begin{array}{c}0.04 \\
(0.7)\end{array}$ & 0.75 & $\begin{array}{c}0.13 \\
(3.6)\end{array}$ & $\begin{array}{r}0.73 \\
(22.7)\end{array}$ & 0.83 & $\begin{array}{r}0.37 \\
(12.5)\end{array}$ & $\begin{array}{r}0.43 \\
(25.2)\end{array}$ & 0.82 \\
\hline 10-year & $\begin{array}{c}0.64 \\
(9.6)\end{array}$ & $\begin{array}{c}0.03 \\
(0.5)\end{array}$ & 0.60 & $\begin{array}{l}-0.01 \\
-(0.4)\end{array}$ & $\begin{array}{r}0.58 \\
(17.4)\end{array}$ & 0.73 & $\begin{array}{c}0.20 \\
(6.4)\end{array}$ & $\begin{array}{r}0.35 \\
(19.8)\end{array}$ & 0.71 \\
\hline 30-year & $\begin{array}{r}0.50 \\
(7.6)\end{array}$ & $\begin{array}{l}-0.01 \\
-(0.1)\end{array}$ & 0.48 & $\begin{array}{r}-0.08 \\
-(2.1)\end{array}$ & $\begin{array}{r}0.36 \\
(10.3)\end{array}$ & 0.50 & $\begin{array}{c}0.10 \\
(3.1)\end{array}$ & $\begin{array}{r}0.25 \\
(13.6)\end{array}$ & 0.53 \\
\hline \multicolumn{10}{|c|}{ With meetings on days of employment reports omitted } \\
\hline 3-month & $\begin{array}{r}0.78 \\
(10.2)\end{array}$ & $\begin{array}{r}0.19 \\
(4.0)\end{array}$ & 0.69 & $\begin{array}{r}0.67 \\
(12.0)\end{array}$ & $\begin{array}{r}0.27 \\
(7.7)\end{array}$ & 0.65 & $\begin{array}{r}0.73 \\
(17.0)\end{array}$ & $\begin{array}{r}0.15 \\
(8.3)\end{array}$ & 0.68 \\
\hline 6-month & $\begin{array}{r}0.83 \\
(10.0)\end{array}$ & $\begin{array}{r}0.17 \\
(3.4)\end{array}$ & 0.67 & $\begin{array}{r}0.61 \\
(15.5)\end{array}$ & $\begin{array}{r}0.36 \\
(14.9)\end{array}$ & 0.81 & $\begin{array}{r}0.69 \\
(19.0)\end{array}$ & $\begin{array}{r}0.20 \\
(13.1)\end{array}$ & 0.76 \\
\hline 12-month & $\begin{array}{r}0.91 \\
(16.6)\end{array}$ & $\begin{array}{c}0.17 \\
(4.9)\end{array}$ & 0.85 & $\begin{array}{r}0.49 \\
(14.0)\end{array}$ & $\begin{array}{r}0.43 \\
(19.7)\end{array}$ & 0.84 & $\begin{array}{r}0.62 \\
(21.2)\end{array}$ & $\begin{array}{r}0.26 \\
(20.3)\end{array}$ & 0.84 \\
\hline 2-year & $\begin{array}{r}0.88 \\
(17.4)\end{array}$ & $\begin{array}{r}0.18 \\
(5.8)\end{array}$ & 0.86 & $\begin{array}{r}0.26 \\
(7.5)\end{array}$ & $\begin{array}{r}0.55 \\
(25.1)\end{array}$ & 0.86 & $\begin{array}{r}0.43 \\
(15.0)\end{array}$ & $\begin{array}{r}0.34 \\
(27.3)\end{array}$ & 0.85 \\
\hline 5-year & $\begin{array}{r}0.71 \\
(9.9)\end{array}$ & $\begin{array}{r}0.17 \\
(3.8)\end{array}$ & 0.67 & $\begin{array}{c}0.11 \\
(2.9)\end{array}$ & $\begin{array}{r}0.55 \\
(22.3)\end{array}$ & 0.82 & $\begin{array}{c}0.26 \\
(8.0)\end{array}$ & $\begin{array}{r}0.35 \\
(24.6)\end{array}$ & 0.80 \\
\hline 10-year & $\begin{array}{r}0.51 \\
(7.0)\end{array}$ & $\begin{array}{c}0.14 \\
(3.1)\end{array}$ & 0.52 & $\begin{array}{c}-0.04 \\
-(1.0)\end{array}$ & $\begin{array}{r}0.43 \\
(17.0)\end{array}$ & 0.73 & $\begin{array}{c}0.10 \\
(2.9)\end{array}$ & $\begin{array}{r}0.28 \\
(19.4)\end{array}$ & 0.70 \\
\hline 30-year & $\begin{array}{c}0.38 \\
(5.3)\end{array}$ & $\begin{array}{r}0.10 \\
(2.2)\end{array}$ & 0.38 & $\begin{array}{l}-0.11 \\
-(2.4)\end{array}$ & $\begin{array}{r}0.27 \\
(10.0)\end{array}$ & 0.50 & $\begin{array}{c}0.00 \\
(0.0)\end{array}$ & $\begin{array}{r}0.20 \\
(13.5)\end{array}$ & 0.52 \\
\hline
\end{tabular}

NOTE: The table shows results of an exercise similar to that in Gürkaynak, Sack, and Swanson (2005), in which one regresses daily interest rate changes on target and path factors, plus a constant (coefficient not shown). Columns 2 through 4 show results using all FOMC events for the October 1988-December 1993 period; columns 5 through 7 show similar results for the January 1994-June 2007 period; and columns 8 through 10 show results for the whole sample. The top panel shows the results for all FOMC meetings; the bottom panel shows the results with employment reports removed. For the top (bottom) panel, the first subsample includes 65 (57) events and the second subsample 112 (111) events, for a total of 177 (168) events. Shaded numbers denote significantly positive (blue) or negative (red) $t$-statistics. 
Fawley and Neely

\section{Figure 1}

\section{Relationship Between Interest Rate Futures and Target and Path Surprises (1994-2007)}
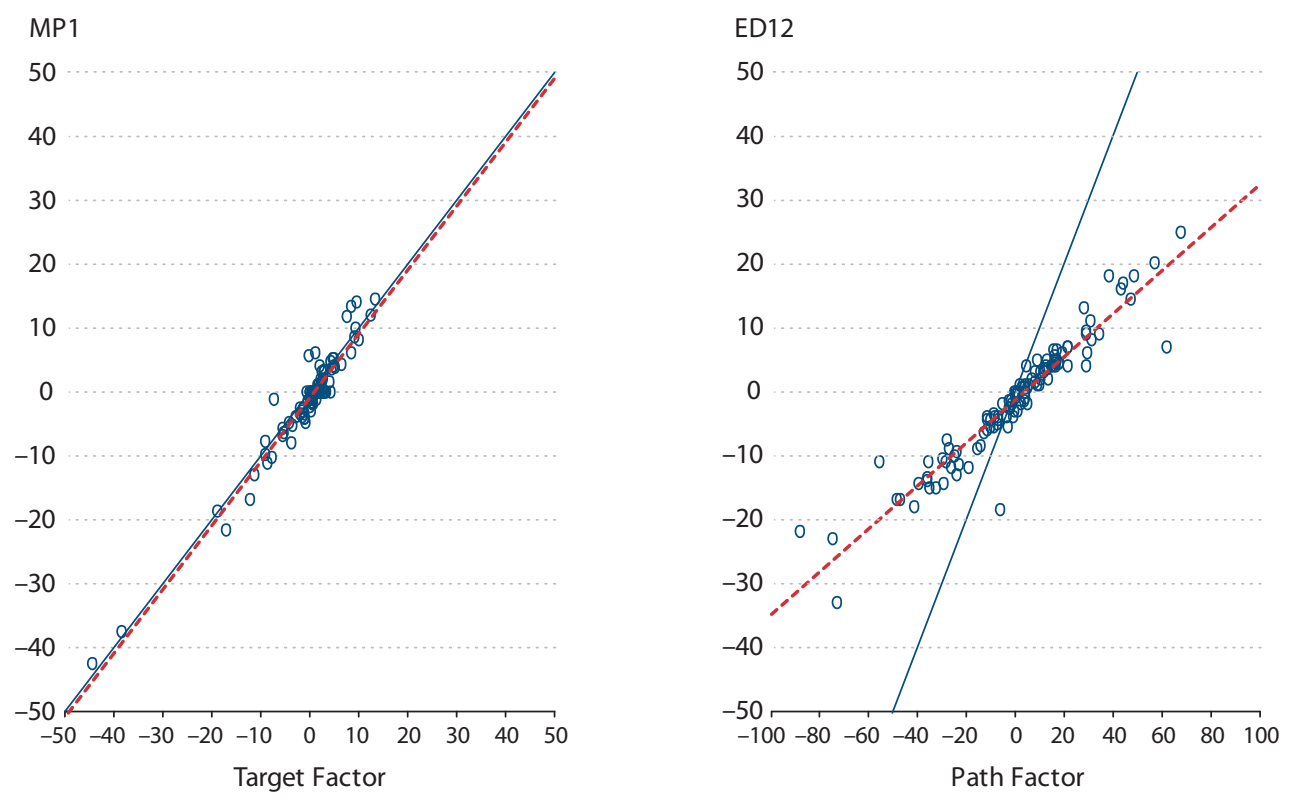

NOTE: MP1 denotes the Kuttner (2001) federal funds shock measured from near-month federal funds futures contracts and ED12 denotes the change in 12-month-ahead eurodollar futures rates, using all FOMC events from 1994 through 2007. The 45-degree blue lines denote a one-toone relationship; the dashed red lines denote the least squares fit from regressing the $y$ variable on the $x$ variable and a coefficient. The slope is determined by construction (see Appendix C).

tion of FOMC meeting statements in 1994 not only improved market confidence in its expectations of the path but also made target surprises less informative.

The bottom panel of Table 5 shows the same regression results but with days of employment reports removed. The target coefficients in the top panel are bigger (artificially inflated) because omitting employment reports from the regression tends to increase the estimated impact of monetary policy. In the bottom panel, the days of employment reports are completely omitted from the sample so there is no omitted variables bias. ${ }^{28}$

Gürkaynak, Sack, and Swanson (2005) emphasize that the path factor is not an independent monetary policy tool, but rather exists because the FOMC can influence medium-term rates by shaping expectations of the target's path. The ability to influence medium-term rates is important because much of monetary policy's effect on the economy occurs through mediumterm rates and the incentives they provide for cyclical spending, such as business and residential investment. In addition, the ability to influence longer-term rates would prove particularly valuable near the zero lower nominal bound.

Although the FOMC does not directly choose the path surprise in the same way that it chooses the federal funds target, the FOMC can strongly influence the path with its meeting statement (Gürkaynak, Sack, and Swanson, 2005). This raises the question of whether such a 


\section{Fawley and Neely}

\section{Figure 2}

\section{Relationship Between Federal Funds Surprises and Eurodollar Futures}
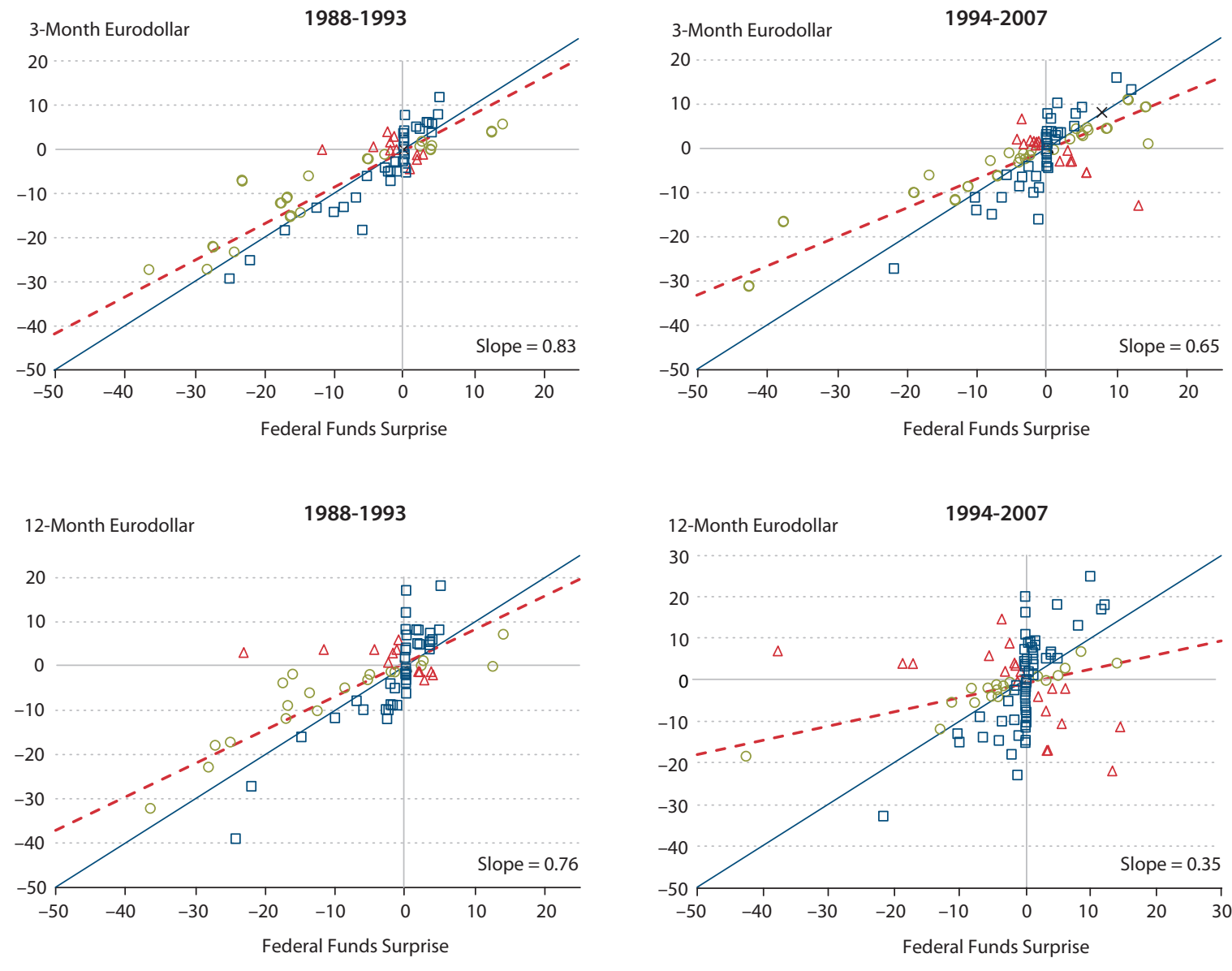

$\times$ One-for-One $\quad \circ$ Less than One-for-One

$\square$ More than One-for-One $\quad \Delta$ Perverse

NOTE: The figure plots changes in 3-month-ahead eurodollar futures (top panel) and 12-month-ahead eurodollar futures (bottom panel) against federal funds rate surprises measured using the methodology of Kuttner (2001). The left (right) column plots all FOMC events for the October 1988-December 1993 period (January 1994-June 2007 period). The solid blue line denotes a one-for-one change in the $x$ and $y$ variables; the dashed red line denotes the OLS fitted line from regression of the $y$ variable on the $x$ variable plus a constant. The slope of this line is identified in the lower-right corner of the figure.

statement reflects a commitment by the FOMC to pursue a certain policy that is inconsistent with its expected reaction function or whether it simply reflects the FOMC's view of the normal policy response to likely economic conditions. Campbell et al. (2012) argue that the FOMC has sufficient experience with communication to influence the economy by committing itself to an unusual policy path. These authors term forward policy guidance that links policy to the forecast of economic activity in the normal way as "Delphic" forward guidance and policy that commits the FOMC to a particular policy as "Odyssean" forward guidance. 
How should the path factor be interpreted? Hausman and Wongswan (2011) show that the somewhat complex Gürkaynak, Sack, and Swanson (2005) transformation of the yield curve to target and path shocks is nearly equivalent to simply using federal funds surprises and changes in the 12-month-ahead eurodollar futures rate. Figure 1 shows this close relation as scatterplots of the federal funds surprises and changes in the 12-month-ahead eurodollar futures rate versus the target and path factors. The data points in the first panel have a 45degree slope by construction (see Appendix C).

The intimate link between changes to year-ahead policy expectations and path surprises raises the question of how the relationship between current target surprises and near-term expectations shifted in 1994. Figure 2 shows a scatterplot of federal funds surprises and corresponding changes in 3-and 12-month-ahead eurodollar rates, along with a 45-degree line denoting one-for-one changes, for two different subsamples. Figures from 1988 to 1993 are shown in the left panel, while figures from 1994 to 2007 are shown in the right panel. Squares (circles) denote surprises that changed eurodollar rates more (less) than one for one. If a surprise to the federal funds target simply moves an expected policy action forward in time, one would expect it to have a less than one-for-one effect on 3- to 12-month interest rates, such as the 3-month eurodollar. In contrast, if a surprise increases expectations of further moves in the same direction, one might expect a more than one-for-one effect on 3- to 12-month interest rates. The panels show that both 3-month and 12-month eurodollar rates responded less strongly - the fitted lines have flatter slopes-to a given target surprise after the FOMC began issuing statements in 1994. This suggests that FOMC target changes produced expectations of less-persistent effects in the latter period.

How do the target and path factors affect asset prices? Tables 6 and 7 show the results of regressing equity and foreign exchange returns and interest rate changes, respectively, on the target and path factors for different samples. ${ }^{29}$ Consistent with Gürkaynak, Sack, and Swanson (2005), the second panels in each table show that the path factor emerges following the FOMC's 1994 decision to issue postmeeting statements. As in Table 5, Table 7 also documents a significant decline in the importance of target surprises to international interest rate changes in the post-1994 sample as FOMC meeting statements made policy surprises relatively less informative. Note that, in both tables, the coefficients on the path factor in the 1988-93 sample are very large-but often statistically insignificant-because of the lack of path factor variation and lack of information in the path factor during that sample.

Statistical methods are not necessarily the only way to identify target and path factors, however. Rosa $(2011 \mathrm{a}, \mathrm{c})$ attempts to identify the second factor using a "narrative" approach in which he first summarizes the tone of each FOMC meeting statement about the future direction of monetary policy and then approximates the unexpected components of the statement by estimating forecasting regressions. Both the surprise component of policy decisions and the statement's tone significantly influence stock prices (Rosa, 2011a) and dollar exchange rates (Rosa, 2011c). The surprise component of the statements accounts for most of monetary policy's effect on asset returns. 
Table 6

Response of the S\&P 500 and Exchange Rates to Target and Path Shocks

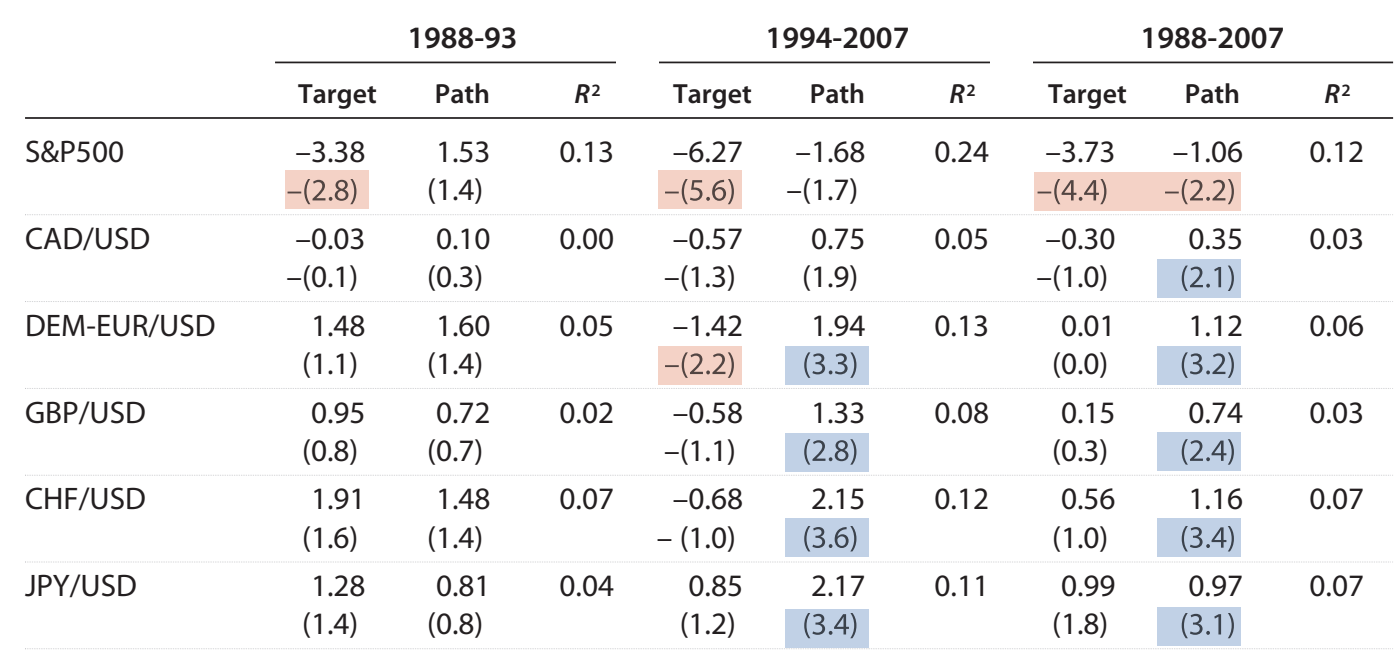

NOTE: The table shows results of an exercise similar to that in Gürkaynak, Sack, and Swanson (2005), in which one regresses daily S\&P 500 and exchange rate returns on target, path factors, and a constant (coefficient not shown). Columns 2 through 4 show results using all FOMC events for the October 1988-December 1993 period; columns 5 through 7 show similar results for the January 1994-June 2007 period; and columns 8 through 10 show results for the whole sample. The first subsample includes 65 events and the second subsample 112 events, for a total of 177 events. Shaded numbers denote significantly positive (blue) or negative (red) $t$-statistics. CAD, Canadian dollar; CHF, Swiss franc; DEM, German deutsche mark; EUR, euro; GBP, British pound; JPY, Japanese yen; USD, U.S. dollar.

\section{International Effects of Monetary Shocks}

The literature on the effects of monetary shocks spurred similar research into the effects of monetary policy shocks on international asset prices. Craine and Martin (2008) extend Rigobon and Sack's (2004) identification-through-heteroskedasticity method to study spillovers of monetary shocks between the United States and Australia, with a special emphasis on accounting for nonmonetary shocks. The authors find that U.S. monetary policy shocks spill over to Australian interest rate and equity markets, but Australian shocks do not seem to affect U.S. financial markets. ${ }^{30}$ Nonmonetary surprises are more important than monetary surprises for long maturity yields and in equities. Valente (2009) follows Craine and Martin's work with a study of the interaction between U.S. monetary policy and the yield curve in Hong Kong and Singapore.

Two-factor methods have also been applied to international data. Hausman and Wongswan (2011) regress interest rate changes, equity index returns, and exchange rate returns in 49 different countries on target and path factors for U.S. monetary policy surprises and obtain results similar to those of Gürkaynak, Sack, and Swanson (2005): Short-term interest rates respond to both path and target surprises, exchange rates and long-term rates respond primarily to path surprises, and equity indexes respond primarily to target surprises. The insensitivity of equity prices to path shocks is somewhat surprising as equity prices should reflect the present value of profits into the infinite future and thus equities should be sensitive to the whole yield 


\section{Table 7}

Response of International Long Yields to Target and Path Shocks

\begin{tabular}{|c|c|c|c|c|c|c|c|c|c|}
\hline & \multicolumn{3}{|c|}{$1988-93$} & \multicolumn{3}{|c|}{ 1994-2007 } & \multicolumn{3}{|c|}{ 1988-2007 } \\
\hline & Target & Path & $R^{2}$ & Target & Path & $R^{2}$ & Target & Path & $R^{2}$ \\
\hline U.S. 10-year & $\begin{array}{c}0.64 \\
(9.6)\end{array}$ & $\begin{array}{c}0.03 \\
(0.5)\end{array}$ & 0.60 & $\begin{array}{l}-0.01 \\
-(0.4)\end{array}$ & $\begin{array}{r}0.58 \\
(17.4)\end{array}$ & 0.73 & $\begin{array}{c}0.20 \\
(6.4)\end{array}$ & $\begin{array}{r}0.35 \\
(19.8)\end{array}$ & 0.71 \\
\hline Canadian10-year & $\begin{array}{r}0.37 \\
(4.1)\end{array}$ & $\begin{array}{c}0.04 \\
(0.4)\end{array}$ & 0.23 & $\begin{array}{c}0.04 \\
(0.7)\end{array}$ & $\begin{array}{r}0.50 \\
(10.8)\end{array}$ & 0.54 & $\begin{array}{r}0.15 \\
(3.5)\end{array}$ & $\begin{array}{r}0.26 \\
(10.5)\end{array}$ & 0.43 \\
\hline German 10-year & & & & $\begin{array}{c}0.05 \\
(1.0)\end{array}$ & $\begin{array}{r}0.21 \\
(5.1)\end{array}$ & 0.21 & $\begin{array}{r}0.11 \\
(2.2)\end{array}$ & $\begin{array}{r}0.12 \\
(5.1)\end{array}$ & 0.20 \\
\hline French 10-year & $\begin{array}{c}0.15 \\
(1.9)\end{array}$ & $\begin{array}{c}-0.02 \\
-(0.3)\end{array}$ & 0.06 & $\begin{array}{r}-0.09 \\
-(2.0)\end{array}$ & $\begin{array}{c}0.03 \\
(0.8)\end{array}$ & 0.04 & $\begin{array}{c}0.00 \\
(0.1)\end{array}$ & $\begin{array}{c}0.04 \\
(1.8)\end{array}$ & 0.02 \\
\hline U.K. 10-year & $\begin{array}{c}0.13 \\
(1.5)\end{array}$ & $\begin{array}{c}-0.03 \\
-(0.3)\end{array}$ & 0.03 & $\begin{array}{r}0.00 \\
-(0.1)\end{array}$ & $\begin{array}{c}0.14 \\
(2.6)\end{array}$ & 0.06 & $\begin{array}{c}0.07 \\
(1.5)\end{array}$ & $\begin{array}{c}0.06 \\
(2.1)\end{array}$ & 0.04 \\
\hline Japanese 10 -year & $\begin{array}{c}0.29 \\
(3.9)\end{array}$ & $\begin{array}{c}0.02 \\
(0.4)\end{array}$ & 0.22 & $\begin{array}{c}0.03 \\
(0.6)\end{array}$ & $\begin{array}{c}0.12 \\
(2.8)\end{array}$ & 0.08 & $\begin{array}{c}0.08 \\
(2.1)\end{array}$ & $\begin{array}{c}0.11 \\
(4.8)\end{array}$ & 0.16 \\
\hline
\end{tabular}

NOTE: The table shows results of an exercise similar to that in Hausman and Wongswan (2011), but using the Gürkaynak, Sack, and Swanson (2005) two-factor methodology, in which one regresses daily international long yields on target, path factors, and a constant (coefficient not shown). Columns 2 through 4 show results using all FOMC events for the October 1988-December 1993 period; columns 5 through 7 show similar results for the January 1994-June 2007 period; and columns 8 through 10 show results for the whole sample. The first subsample includes 65 events and the second subsample 112 events, for a total of 177 events. Shaded numbers denote significantly positive (blue) or negative (red) t-statistics.

curve. As in Tables 5 and 6, Table 7 shows a strong path factor effect on foreign long rates after 1993.

\section{CONCLUSION}

The speed and flexibility with which monetary policy can be employed has made it the primary policy for macroeconomic stabilization. The importance of this policy for inflation, output, and employment has motivated researchers to explore its impact on the economy. Because of the difficulty in directly discerning the impact of monetary policy on monthly and quarterly macroeconomic variables, researchers have studied the effect of such policies on quick-reacting asset prices as a first step in understanding the broader implications of monetary policy for macro variables. A key lesson from this literature is that researchers must properly account for Federal Reserve procedures to draw the correct inference about the impact of monetary surprises. Specifically, the increasing transparency of Fed procedures and objectives, coupled with credibility won over several decades, has enabled the FOMC to influence asset prices with statements rather than large and disruptive surprises in overnight interest rates.

Early research on the effects of low-frequency changes in monetary or reserve aggregates found no consistent effect of these variables on asset prices, despite the Fed's description of 


\section{Fawley and Neely}

its own objectives in terms of the former variables. But Cook and Hahn (1989) found strong effects of federal funds target changes-the FOMC's monetary policy instrument-in the 1970s. Kuttner (2001) established the importance of decomposing policy actions into expected and unexpected components with data from federal funds futures markets, as asset prices should respond only to the unexpected component. Other researchers (e.g., Poole, Rasche, and Thornton, 2002, and Hamilton, 2008) advocated methods that are robust to the measurement error inherent in constructing monetary surprises.

FOMC procedural changes, particularly those in 1994-95, have influenced researchers' methods. The FOMC greatly reduced the frequency of intermeeting target changes, announced target changes as they were decided, and began to issue postmeeting statements to guide public understanding of the economy and likely future monetary policy. These changes reduced the necessity of accounting for other news that might affect asset prices and the simultaneity of monetary policy and asset price changes (Rigobon and Sack, 2004). In addition, the resultant increased Fed transparency has greatly improved the market's ability to forecast and price in monetary policy actions well before they happen (e.g., Poole, Rasche, and Thornton, 2002, and Swanson, 2006).

An apparent disconnect of movements in longer-term interest rates from federal funds surprises led researchers to realize they should account for the effect of FOMC policy statements on year-ahead interest rates (Bernanke and Kuttner, 2005; Gürkaynak, Sack, and Swanson, 2005). In the post-1994 sample, these path surprises significantly affect exchange rates and international interest rates across the yield curve; however, they do not affect U.S. or international equity prices. Gürkaynak, Sack, and Swanson (2005) argue that the influence of these path surprises indicates that the Fed can credibly commit to a policy path.

Researchers have used such institutional knowledge to establish that monetary policy surprises influence the prices of many asset classes, including fixed income, equity, and foreign exchange. They have also investigated the impact of monetary policy surprises on equity prices from different types of firms and industries and what that reveals about the relative importance of the asset price and credit channels of monetary policy (Ehrmann and Fratzcher, 2004, 2009; Basistha and Kurov, 2008). Most recently, researchers have found considerable international impact of monetary policy surprises (Craine and Martin, 2008; Hausman and Wongswan, 2011). 


\section{APPENDIXES}

\section{Appendix A: Expectations of the Federal Funds Target from Futures Prices}

The Chicago Board of Trade has sponsored trading in the 30-day federal fund futures contract - an interest rate derivative-since October 3, 1988. Emmons, Lakdawala, and Neely (2006) describe federal funds futures and options on those futures in some detail.

The federal funds futures market is a derivatives market whose final settlement price is determined by the average federal funds rate over the contract month. Thus, the final settlement price on the March 2013 contract is determined by the average federal funds rate during that month. If the contract month has $M$ trading days, the final settlement price (price settle,t $^{2}$ will be

$$
\text { price }^{\text {settle,t }}=1-\text { ff }^{\text {settle, },}=1-\frac{1}{M} \sum_{j=1}^{M} f f_{j}^{t},
$$

where $f f^{\text {settle, } t}$ is the average federal funds rate implied by the final settlement price.

On day $i$, the federal funds futures rate implied by the day $i$ future price $\left(f f_{i}^{t}=1-\right.$ Price $\left._{i}^{t}\right)$ for a given contract month, $t$, is equal to the expected final settlement price plus a risk premium:

$$
f f_{i}^{t}=E_{i} f f^{\text {settle,t }}+r p_{i}^{t}=E_{i} \frac{1}{M} \sum_{j=1}^{M} f f_{j}^{t}+r p_{i}^{t} .
$$

Piazzesi and Swanson (2008) show that implied federal funds rates from futures are modestly biased predictors, likely to slightly overpredict the rate implied by final futures settlement by 3 to 6 basis points per month of forecast horizon, on average. The authors estimate the following regression with heteroskedastic-consistent errors: $f_{t}^{n}-r_{t+n}=\alpha^{(n)}+\varepsilon_{t+n}^{t}$, where $f_{t}^{n}$ is the $n$-periodahead rate implied by the federal funds futures price in month $t$ and $r_{t+n}$ is the actual (realized, ex post) average funds rate in month $t+n$. For values of $n=\{1,2,3,4$, and 5$\}, \alpha^{(n)}=\{3.4,7.4$, $12.5,19.2,27.6$, and 36.7$\}$, respectively. Some analysts argue that such risk premia are too large to be plausible (Carlson, Craig, and Melick, 2005). But because the risk premium changes very slowly-at business cycle frequencies-daily changes in federal funds futures prices closely approximate daily changes in the market's expectation of the funds target (Piazzesi and Swanson, 2008).

The New York Fed is able to keep the actual federal funds rate "close" to the federal funds target desired by the FOMC. Therefore, the average federal funds rate over a month will be very close to the average federal funds targets for that month:

$$
\frac{1}{M} \sum_{j=1}^{M} f f_{j}^{t} \approx \frac{1}{M} \sum_{j=1}^{M} f f_{j}^{\text {target }, t} .
$$

If there is an FOMC meeting within a month, on day $d$ of the month, the average federal funds target will be a weighted average of the (known) target prior to the FOMC meeting and the new target chosen at the FOMC meeting:

$$
\frac{1}{M} \sum_{j=1}^{M} f f_{j}^{t} \approx \frac{1}{M} \sum_{j=1}^{d} f f_{j}^{\text {target }, t}+\frac{1}{M} \sum_{j=d+1}^{M} f f_{j}^{\text {target }, t} .
$$




\section{Fawley and Neely}

If we denote the known target going into the meeting as $f f_{\text {start }}^{\text {target } t}$ and the target chosen at the

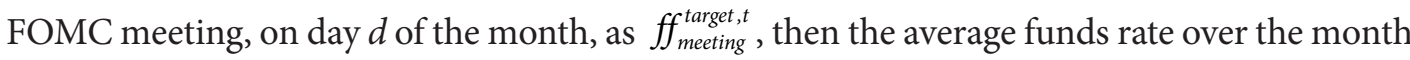
is equal to

$$
\frac{1}{M} \sum_{j=1}^{M} f f_{j}^{t} \approx \frac{d}{M} f f_{\text {start }}^{\text {target }, t}+\frac{M-d}{M} \int f_{\text {meeting }}^{\text {target, }}
$$

or, solving for the target to be chosen at the FOMC meeting:

$$
f f_{\text {meeting }}^{\text {target }} \approx \frac{M}{M-d}\left(\frac{1}{M} \sum_{j=1}^{M} f f_{j}^{t}-\frac{d}{M} f f_{\text {start }}^{\text {target }, t}\right) \text {. }
$$

Using the fact that the average expected funds rate for a target month is equal to the funds rate implied by the current futures prices $\left(f f_{i}^{t}=E_{i} \frac{1}{M} \sum_{j=1}^{M} f f_{j}^{t}+r p_{i}^{t}\right)$, the expected target, as of day $i$, at the FOMC meeting in month $t$ can be written as follows:

$$
E_{i}\left(f f_{\text {meeting }}^{\text {target }}\right) \approx \frac{M}{M-d}\left(f f_{i}^{t}-r p_{i}^{t}-\frac{d}{M} f f_{\text {start }}^{\text {target }, t}\right) .
$$

If the FOMC meeting day is near the end of the contract month, then $M-d$ will be small and the calculation will be very sensitive to small errors in the data, perhaps caused by bid-ask spreads. In this case, it is better to use the next month's contract-when there will be no FOMC meeting - to estimate the market's expectation of the FOMC decision. For relatively short forecast horizons, researchers commonly ignore the risk premium in equation (A.7), assuming that it will be very small.

Equation (A.7) can be used to decompose FOMC target changes into expected and surprise components. The expected change in the federal funds target is the expected target at the meeting less the current (start of month) target, expressed as

$$
\begin{aligned}
E_{i}\left(\Delta f f_{\text {meeting }}^{\text {target }}\right) & =E_{i}\left(f f_{\text {meeting }}^{\text {target } t}\right)-f f_{\text {start }}^{\text {target } t} \\
& \approx \frac{M}{M-d}\left(f f_{i}^{t}-r p_{i}^{t}-\frac{d}{M} \int f_{\text {start }}^{\text {target }, t}\right)-f f_{\text {start }}^{\text {target }, t} \\
& \approx \frac{M}{M-d}\left(f f_{i}^{t}-r p_{i}^{t}-\frac{d}{M} \int f_{\text {start }}^{\text {target }, t}-\frac{M-d}{M} f f_{\text {start }}^{\text {target }, t}\right) \\
& \approx \frac{M}{M-d}\left(f f_{i}^{t}-r p_{i}^{t}-\frac{M}{M} \int f_{\text {start }}^{\text {target }, t}\right) \\
& \approx \frac{M}{M-d}\left(f f_{i}^{t}-r p_{i}^{t}-f f_{\text {start }}^{\text {target }, t}\right) . \\
E_{i}\left(\Delta f f_{\text {meeting }}^{\text {target } t}\right)= & E_{i}\left(f f_{\text {meeting }}^{\text {target } t}\right)-f f_{\text {start }}^{\text {target }, t} \approx \frac{M}{M-d}\left(f f_{i}^{t}-r p_{i}^{t}-f f_{\text {start }}^{\text {target }, t}\right) .
\end{aligned}
$$

The surprise component $\left(\tilde{f f}_{\text {meeting }}^{\text {tareet } t}\right)$ is the actual change less the change that was expected just before the meeting: 


$$
\tilde{\Delta} f f_{\text {meeting }}^{\text {target }, t}=\Delta f f_{\text {meeting }}^{\text {target } t}-E_{i}\left(\Delta f f_{\text {meeting }}^{\text {target } t}\right)
$$

Kuttner (2001) recognizes that a time-varying risk premium, $r p_{i}^{t}$, potentially contaminates the federal funds shocks calculated from equations (A.9) and (A.10), and that the multiplier $\frac{M}{M-d}$ amplifies this measurement error, particularly near the end of the month. Therefore, he proposes a more robust estimate of federal funds shocks using changes in futures prices around FOMC events. Specifically, he observes that the futures price in equation (A.7) can be solved for to obtain the following:

$$
f f_{i}^{t}=\frac{M-d}{M} E_{i}\left(f f_{\text {meeting }}^{\text {target } t}\right)+\frac{d}{M} f f_{\text {start }}^{\text {target }, t}+r p_{i}^{t},
$$

which implies that a daily difference in the futures price should estimate the sum of the daily change in the target for month $t$ plus the daily difference in the risk premium:

$$
f f_{i}^{t}-f f_{i-1}^{t}=\frac{M-d}{M} \Delta E_{i}\left(f f_{\text {meeting }}^{\text {target }}\right)+r p_{i}^{t}-r p_{i-1}^{t} .
$$

If the day-to-day change in the risk premium is small, then he can estimate the policy surprise-that is, the change in the expected target on the day of the meeting-as follows:

$$
\tilde{\Delta} f f_{\text {meeting }}^{\text {target }}=\frac{M}{M-d}\left(f f_{i}^{t}-f f_{i-1}^{t}\right) \text {. }
$$

Changes in futures prices around FOMC events reflect unanticipated changes to the funds rate. While surprises calculated from equation (A.13) may still suffer from measurement error, they remain robust under much weaker assumptions about the sources of such error.

\section{Appendix B: Simultaneity and Omitted Bias}

The monetary policy shock literature typically seeks to determine the effect of monetary policy on some function of asset prices. Researchers have been primarily concerned with the effect of some function of monetary policy $\left(\Delta m_{t}\right)$ on some function of asset prices $\left(\Delta p_{t}\right)$, which could include changes in bond yields, stock prices, or exchange rates, but the relation could also include other news, such as macroeconomic releases $\left(n e w s_{t}\right)$, and/or other variables:

$$
\Delta p_{t}=a_{1} \Delta m_{t}+a_{2} n e w s_{t}+e_{p, t} .
$$

Although we would like to estimate the parameter, $a_{1}$, if monetary policy reacts to asset price changes within the observation interval for the data (e.g., within the day for daily data), then $b_{1}$ will be nonzero in equation (B.2) and this will affect the estimation of equation (B.1):

$$
\Delta m_{t}=b_{1} \Delta p_{t}+b_{2} n e w s_{t}+e_{m, t} .
$$

For simplicity of notation, we assume that all variables are known to be mean zero and that the structural errors, $e_{p, t}$ and $e_{m, t}$, are uncorrelated over time and contemporaneously. 


\section{Fawley and Neely}

They have diagonal covariance matrix $V$ and are also uncorrelated with exogenous news shocks, whose variance is normalized to equal 1. Equations (B.1) and (B.2) can be written in terms of the matrixes, $\mathrm{M}, \mathrm{P}, \mathrm{N}, \mathrm{E}_{\mathrm{m}}$, and $\mathrm{E}_{\mathrm{p}}$, which represent the $\mathrm{T} \times 1$ vectors whose th elements are $\Delta m_{t}, \Delta p_{t}, n e w s_{t}, e_{m, t}$, and $e_{p, t}$, respectively:

$$
\begin{aligned}
& \mathrm{P}=\mathrm{M} a_{1}+\mathrm{N} a_{2}+\mathrm{E}_{p} \\
& \mathrm{M}=\mathrm{P} b_{1}+\mathrm{N} b_{2}+\mathrm{E}_{m} .
\end{aligned}
$$

Or, this can be written in matrix form:

$$
\left[\begin{array}{ll}
P & M
\end{array}\right]\left[\begin{array}{cc}
1 & -b_{1} \\
-a_{1} & 1
\end{array}\right]=N\left[\begin{array}{ll}
a_{2} & b_{2}
\end{array}\right]+\left[\begin{array}{ll}
E_{p} & E_{m}
\end{array}\right]
$$

and equation (B.5) can be rewritten as follows:

$$
\left[\begin{array}{ll}
P & M
\end{array}\right]=N D C^{-1}+\left[\begin{array}{ll}
E_{p} & E_{m}
\end{array}\right] C^{-1},
$$

where $D=\left[\begin{array}{ll}a_{2} & b_{2}\end{array}\right], C=\left[\begin{array}{cc}1 & -b_{1} \\ -a_{1} & 1\end{array}\right]$, and so $C^{-1}=\frac{1}{1-a_{1} b_{1}}\left[\begin{array}{cc}1 & b_{1} \\ a_{1} & 1\end{array}\right]$. The following matrixes are used to define the unconditional covariance matrix of the endogenous variables:

$$
\begin{aligned}
& C^{-1^{\prime}} D^{\prime} N^{\prime} N D C^{-1}=N^{\prime} N\left(\frac{1}{1-a_{1} b_{1}}\right)^{2}\left[\begin{array}{cc}
\left(a_{2}+a_{1} b_{2}\right)^{2} & \left(b_{1} a_{2}+b_{2}\right)\left(a_{2}+a_{1} b_{2}\right) \\
\left(b_{1} a_{2}+b_{2}\right)\left(a_{2} b_{1}+b_{2}\right) & \left(b_{1} a_{2}+b_{2}\right)^{2}
\end{array}\right] \\
& C^{-1^{\prime}} V C^{-1}=\frac{1}{\left(1-a_{1} b_{2}\right)^{2}}\left[\begin{array}{cc}
V_{11}+a_{1}^{2} V_{22} & b_{1} V_{11}+a_{1} V_{22} \\
b_{1} V_{11}+a_{1} V_{22} & b_{1}^{2} V_{11}+V_{22}
\end{array}\right] \text {, }
\end{aligned}
$$

where $V_{11}$ and $V_{22}$ are the variances of the structural errors of the price and money equations.

The OLS estimates of the parameters in equation (B.3) are as follows:

$$
\left[\begin{array}{l}
\hat{a}_{1} \\
\hat{a}_{2}
\end{array}\right]=\left[\begin{array}{ll}
M^{\prime} M & M^{\prime} N \\
M^{\prime} N & N^{\prime} N
\end{array}\right]^{-1}\left[\begin{array}{c}
M^{\prime} P \\
N^{\prime} P
\end{array}\right]=\left[\begin{array}{cc}
M^{\prime} M & M^{\prime} N \\
M^{\prime} N & N^{\prime} N
\end{array}\right]^{-1}\left[\begin{array}{c}
M^{\prime} M a_{1}+M^{\prime} N a_{2}+M^{\prime} E_{p} \\
N^{\prime} M a_{1}+N^{\prime} N a_{2}+N^{\prime} E_{p}
\end{array}\right] .
$$

Taking the inverse, multiplying through, and eliminating terms that are identically zero yields the following expression for the OLS estimates:

$$
\left[\begin{array}{l}
\hat{a}_{1} \\
\hat{a}_{2}
\end{array}\right]=\frac{1}{M^{\prime} M N^{\prime} N-\left(M^{\prime} N\right)^{2}}\left[\begin{array}{c}
\left(N^{\prime} N M^{\prime} M-M^{\prime} N N^{\prime} M\right) a_{1}+\left(N{ }^{\prime} N M^{\prime}-M^{\prime} N N^{\prime}\right) E_{P} \\
\left(M^{\prime} M N^{\prime} N-M^{\prime} N M^{\prime} N\right) a_{2}+\left(M^{\prime} M N^{\prime}-M^{\prime} N M^{\prime}\right) E_{P}
\end{array}\right]
$$


The behavior of the coefficients in large samples is given by the probability limits (plims) of the expressions in (B.10), if the limits exist:

$$
\operatorname{plim}_{T \rightarrow \infty}\left[\begin{array}{l}
\hat{a}_{1} \\
\hat{a}_{2}
\end{array}\right]=\left[\begin{array}{l}
a_{1} \\
a_{2}
\end{array}\right]+\operatorname{plim}_{T \rightarrow \infty}\left[\frac{1}{M^{\prime} M N N^{\prime} N-\left(M^{\prime} N\right)^{2}}\left[\begin{array}{c}
N^{\prime} N M^{\prime} E p \\
-M^{\prime} N M^{\prime} E_{p}
\end{array}\right]\right] .
$$

Fortunately, the rules of probability limits allow us to pass the plim function through products and quotients. That is, the plim of a product is the product of its plims, and the plim of a quotient is the quotient of the plims. This allows us to determine the plims of the coefficient estimators in equation (B.11). We use the following limits:

$$
\begin{gathered}
\operatorname{plim}_{T \rightarrow \infty} \frac{1}{T} N^{\prime} N=1 \\
\operatorname{plim}_{T \rightarrow \infty} \frac{1}{T^{2}}\left(M^{\prime} M^{\prime} N-\left(M^{\prime} N\right)^{2}\right)=\frac{b_{1}^{2} V_{11}+V_{22}}{\left(1-a_{1} b_{1}\right)^{2}} \\
\operatorname{plim}_{T \rightarrow \infty} \frac{1}{T} M^{\prime} E_{p}=\frac{V_{11} b_{1}}{1-a_{1} b_{1}} \\
\operatorname{plim}_{T \rightarrow \infty}\left[M^{\prime} M\right] / T=\left[\frac{\left(b_{1} a_{2}+b_{2}\right)^{2}+b_{1}^{2} V_{11}+V_{22}}{\left(1-a_{1} b_{1}\right)^{2}}\right] \\
\operatorname{plim}\left[\frac{1}{T} M^{\prime} N\right]=\frac{a_{2} b_{1}+b_{2}}{1-a_{1} b_{1}} .
\end{gathered}
$$

Equation (B.14) uses the assumption that the structural errors are uncorrelated with the news shocks-that is, $\underset{T \rightarrow \infty}{\operatorname{plim}}\left(\frac{1}{T} N^{\prime} E_{p}\right)=0$. Using these probability limits in (B.11), we obtain the following:

$$
\operatorname{plim}_{T \rightarrow \infty}\left[\begin{array}{l}
\hat{a}_{1} \\
\hat{a}_{2}
\end{array}\right]=\left[\begin{array}{l}
a_{1} \\
a_{2}
\end{array}\right]+\frac{\left(1-a_{1} b_{1}\right)^{2}}{\left(b_{1}^{2} V_{11}+V_{22}\right)}\left[\begin{array}{c}
\frac{V_{11} b_{1}}{1-a_{1} b_{1}} \\
-\left(\frac{a_{2} b_{1}+b_{2}}{1-a_{1} b_{1}}\right)\left(\frac{V_{11} b_{1}}{1-a_{1} b_{1}}\right)
\end{array}\right]=\left[\begin{array}{c}
a_{1} \\
a_{2}
\end{array}\right]+\frac{b_{1}}{\left(b_{1}^{2}+V_{22} / V_{11}\right)}\left[\begin{array}{c}
\left(1-a_{1} b_{1}\right) \\
-\left(a_{2} b_{1}+b_{2}\right)
\end{array}\right] .
$$

Note that the OLS estimation of an equation with an endogenous regressor $\left(\Delta m_{t}\right)$-that is, $b_{1} \neq 0$-will generally produce inconsistent estimates of both regressors. ${ }^{31}$ In this case, the OLS estimate, $\hat{a}_{1}$, is consistent if the variance of the structural asset price shocks equals zero $\left(V_{11}=0\right)$ or if $\Delta p_{t}$ has no contemporaneous effect on $\Delta m_{t}$; that is, $b_{1}=0$, in which case $\Delta p_{t}$ would be considered predetermined. Otherwise, if the ratio of variance of monetary policy shocks to the variance of price shocks $\left(V_{22} / V_{11}\right)$ gets arbitrarily large, then $\hat{a}_{1}$ will converge in probability to $a_{1}$. 
One way to drive the variance ratio $\left(V_{22} / V_{11}\right)$ of the structural shocks arbitrarily large is to take an arbitrarily short interval around the monetary policy event-an FOMC announcement, for example. In such an interval, the variance of monetary shocks will be very large and the variance of prices can be made arbitrarily small. Also, in such a short interval, the monetary authorities are very unlikely to be reacting to any changes in asset prices, which means that $\Delta p_{t}$ has no contemporaneous effect on $\Delta m_{t}$; that is, $b_{1}=0$.

Note too that if the news variables in equation (B.4) are omitted from the estimated regression, there is a different problem: omitted variables bias. In this case, the OLS estimate of the coefficient on the monetary shock, $a_{1}$, is as follows:

$$
\hat{a}_{1}=\left[M^{\prime} M\right]^{-1} M^{\prime} P=\left[M^{\prime} M\right]^{-1}\left[M^{\prime} M a_{1}+M^{\prime} N a_{2}+M^{\prime} E_{p}\right]
$$

Again, we can use the plims that exist for $\frac{1}{T} M^{\prime} M, \frac{1}{T} M^{\prime} N$, and $\frac{1}{T} M^{\prime} E_{p}$ to show that

$$
\operatorname{plim}_{T \rightarrow \infty} \hat{a}_{1}=a_{1}+\frac{\left(1-a_{1} b_{1}\right)\left(\left(a_{2} b_{1}+b_{2}\right) a_{2}+V_{11} b_{1}\right)}{\left(b_{1} a_{2}+b_{2}\right)^{2}+\left(b_{1}^{2} V_{11}+V_{22}\right)} .
$$

If $a_{2}=0$, there is no omitted variable, but simultaneity $\left(b_{1} \neq 0\right)$ still creates inconsistency:

$$
\operatorname{plim}_{T \rightarrow \infty} \hat{a}_{1}=a_{1}+\frac{\left(1-a_{1} b_{1}\right) b_{1}}{b_{2}^{2} / V_{11}+b_{1}^{2}+V_{22} / V_{11}} .
$$

If $b_{1}=0$, then the monetary policy shock is predetermined; there is no simultaneity. In this case, if either $b_{2}$ or $a_{2}$ were also zero-that is, news does not contemporaneously affect both asset prices and monetary-then equation (B.19) shows that $\hat{a}_{1}$ would be consistent. Otherwise-still assuming that $b_{1}=0$-then as the effect of news on monetary policy $\left(b_{2}\right)$ or the variance of monetary policy shocks $\left(V_{22}\right)$ gets arbitrarily large, the estimate approaches consistency (see below):

$$
\operatorname{plim}_{T \rightarrow \infty} \hat{a}_{1}=a_{1}+\frac{b_{2} a_{2}}{b_{2}^{2}+V_{22}}=a_{1}+\frac{a_{2}}{b_{2}+V_{22} / b_{2}} .
$$

\section{Appendix C: Target and Path Surprises}

Gürkaynak, Sack, and Swanson (2005) identify monetary policy shocks as the unobserved monetary factors $F$ from

$$
X=F \Lambda+\eta
$$

where $\eta$ are white-noise disturbances and $\Lambda$ contains the loadings of $F$ on $X$. Gürkaynak, Sack, and Swanson (2005) include five variables in $X$ : (i) the surprise to the federal funds target measured from current-month federal funds futures; (ii) the surprise change in expectations of the federal funds target two FOMC meetings ahead, measured from the appropriate federal 


\section{Table C1}

\section{Response of Federal Funds Surprises and 12-Month Eurodollar Futures to the Normalized Target and Path Factors}

\begin{tabular}{|c|c|c|c|c|c|c|c|c|c|}
\hline & \multicolumn{3}{|c|}{ 1988-93 } & \multicolumn{3}{|c|}{ 1994-2007 } & \multicolumn{3}{|c|}{ 1988-2007 } \\
\hline & Target & Path & $R^{2}$ & Target & Path & $R^{2}$ & Target & Path & $R^{2}$ \\
\hline MP1 & $\begin{array}{r}1.12 \\
(15.3)\end{array}$ & $\begin{array}{c}0.00 \\
(0.0)\end{array}$ & 0.79 & $\begin{array}{r}0.93 \\
(40.5)\end{array}$ & $\begin{array}{c}0.00 \\
(0.0)\end{array}$ & 0.94 & $\begin{array}{r}1.00 \\
(41.6)\end{array}$ & $\begin{array}{c}0.00 \\
(0.0)\end{array}$ & 0.91 \\
\hline ED12 & $\begin{array}{r}1.22 \\
(25.0)\end{array}$ & $\begin{array}{l}(0.02) \\
(0.5)\end{array}$ & 0.91 & $\begin{array}{r}0.31 \\
(16.6)\end{array}$ & $\begin{array}{r}1.01 \\
(59.9)\end{array}$ & 0.97 & $\begin{array}{r}0.58 \\
(41.0)\end{array}$ & $\begin{array}{r}0.58 \\
(70.9)\end{array}$ & 0.97 \\
\hline
\end{tabular}

NOTE: The table shows the result of regressing the federal funds surprise (MP1) and the daily change in 12-month eurodollar futures (ED12) on the target and path factors used as regressors in Tables 5 through 7. The full sample results (1988-2007) show the effect of the normalization procedure, while the subsample results (1988-93 and 1994-2007) show the effect of sampling variation.

funds future contract; and the price change in (iii) 6-month, (iv) 9-month, and (v) 12-month eurodollar futures contracts.

Gürkaynak, Sack, and Swanson (2005) structurally identify the two monetary policy factors, $F$, as a linear transformation of the first two principal components $(Z)$ of $X$. Specifically,

$$
F=Z U,
$$

where $Z$ is the first two principal components of $X$, and $U$ is a $2 \times 2$ matrix whose elements are identified by imposing the following restrictions: (i) the columns of $U$ have unit length, (ii) the columns of $F$ are orthogonal, and (iii) $F_{2}$, the second column of $F$, does not influence the current federal funds shock. The last restriction, which implies two equations, provides the structural interpretation of $F_{1}$ and $F_{2}$ as the target and path surprise, respectively. In other words, $F_{1}$ contains all information from the first two principal components that explains the current federal funds surprise, and $F_{2}$ contains all residual information.

Finally, Gürkaynak, Sack, and Swanson (2005) rescale $F_{1}$ and $F_{2}$ to provide comparability between coefficients and against earlier studies. Specifically, they scale $F_{1}$ to move one for one with the current federal funds surprise (MP1) and $F_{2}$ to have the same magnitude effect on 12-month eurodollar futures (ED12) as $F_{1}$. Table $\mathrm{C} 1$ illustrates the relationship between MP1 and ED12 and the normalized target and path factors used as regressors in Tables 5 through 7. Please note the effect of sampling variation when comparing the size of subsample coefficients in Tables 5 through 7 with previous studies. 


\section{Fawley and Neely}

\section{NOTES}

1 The Romer and Romer $(1989,1994)$ narrative approach is another method to identify monetary policy shocks. The terms "shocks" and "surprises" are closely related but not quite synonymous. A "shock" denotes the unexpected component of a variable in a statistical model. Some researchers reserve the term for the unexpected component of a variable in a structural statistical model. In contrast, a "surprise" denotes any unexpected occurrence, particularly an event that markets did not expect. Most of the research discussed in this article uses statistical methods in which expectations are derived from futures market prices, in which case there is no distinction between shocks and surprises.

2 This paper focuses on the literature studying the reactions to conventional monetary policy shocks, not on reactions to the unconventional policies, including long-term security purchases, which debuted in 2008.

3 The federal funds market is an overnight market in which depository institutions lend reserve balances to other depository institutions.

4 In a regression, the omission of relevant explanatory variables will generally bias the estimated coefficients on included variables, unless the omitted explanatory variables happen to be uncorrelated with the included variables.

5 Friedman (1968) argued that "interest rates are such a misleading indicator of whether monetary policy is 'tight' or 'easy.'" He viewed nominal interest as reflecting the stance of past monetary policy via inflation expectations.

6 Early studies measured the unexpected component of money growth as the residuals from a univariate or multivariate autoregressive model of money growth (Barro, 1978) or as the difference between announced money growth and Money Market Services (MMS) median survey forecasts (Cornell, 1982, 1983; Hardouvelis, 1984).

7 The Federal Reserve did not begin announcing a numerical federal funds target in its statement until July 1995 (Middeldorp, 2011), but it has published an official federal funds target dating back to 1982 (http://research.stlouisfed.org/fred2/series/DFEDTAR?cid=118).

Although a monetary policy instrument is not the same as the monetary policy stance-for example, "high" nominal interest rates do not necessarily indicate tight policy if inflation expectations are sufficiently high —a discrete change in the instrument typically implies a discrete change in the stance as price levels and inflation expectations typically do not "jump" to offset a change in the instrument.

8 The end of Cook and Hahn's (1989) sample coincides with Chairman Volcker's decision to deemphasize the role of the federal funds rate in setting monetary policy. Cook and Hahn (1989) document the market's adeptness at interpreting pre-1994, unannounced policy changes from open market operations. Cook and Hahn (1988) find that when discount rate changes signaled federal funds changes, they also moved interest rates. This result held in their 1973-79 and 1979-85 subsamples.

9 Roley and Sellon (1995) do find some evidence that 30-year Treasury yields anticipate future policy.

${ }^{10}$ Fatum and Scholnick (2008) confirm this finding and argue that failing to correctly model the unexpected component of monetary policy news leads to underestimating the effects of such news. They also confirm that systematic reactions occur rapidly, within the day of the announcement.

11 Poole, Rasche, and Thornton (2002) present evidence that markets were commonly able to predict policy actions at least two weeks ahead after 1994.

12 Surprises measured with futures data also contain some measurement error from bid-ask spreads and risk premia, but probably much less than other methods.

${ }^{13}$ Some researchers have used longer-term interest rates to identify shocks on the grounds that they better measure surprising actions by the Fed while minimizing measurement error when only the timing of the action is a surprise. For example, if the Fed surprises markets by lowering interest rates one meeting earlier than expected, then near-month federal funds futures will measure a large surprise, while 3-month eurodollar futures might remain unchanged. Cochrane and Piazzesi (2002) measure policy surprises from 1-month eurodollar deposit rates; Ellingsen and Soderstrom (2004) use the 3-month Treasury bill rate; Rigobon and Sack (2004) use the 3-month eurodollar futures rate; and Bomfim (2003), Poole and Rasche (2000), and Poole, Rasche, and Thornton (2002) use month-ahead federal funds futures. Bernanke and Kuttner (2005) check the robustness of their results to those obtained with 3-month eurodollar futures. 
${ }^{14}$ Rigobon and Sack (2008) argue that correcting for the noise in macroeconomic announcements significantly increases the implied information content of those announcements.

15 Piazzesi and Swanson (2008) argue that risk premia on federal funds futures are small and fairly stable at a daily frequency (also see Hamilton, 2009).

${ }^{16}$ Hamilton's (2008) methodology nests Kuttner's (2001) specification when the effective federal funds rate always equals the target and the dates of policy actions are known.

17 Gürkaynak, Sack, and Swanson (2005) note a number of instances in which major news was released on days of FOMC meetings or target changes.

${ }^{18}$ Thornton (2001a) describes the shift away from unilateral discretion for the chairman to adjust the funds target in favor of consultation with the FOMC before making any changes.

${ }^{19}$ In this context, "identification" means that the assumed model permits one to sort out the two-way causality in asset price changes and FOMC actions. That is, the assumed data-generating process in equations (3) and (4) must permit consistent estimation of $a_{1}$ and $b_{1}$ if the contemporaneous effects are to be considered identified.

Gürkaynak, Sack, and Swanson (2005) find that policy surprises constructed from federal funds futures in 30minute and 1-day windows around policy events are nearly identical; the only notable deviations occur on pre1994 event days that coincide with the release of the employment report.

20 The results are somewhat sensitive to the inclusion of the semiannual report to Congress.

${ }^{21}$ Narrow event windows might not capture the full impact on asset prices. Fleming and Piazzesi (2005) report that, with the exception of intermeeting moves, asset prices respond very quickly to FOMC announcements.

22 In the context of borrowing and lending, adverse selection is the tendency of individuals and firms with bad credit to be more likely to seek loans from banks. Moral hazard is the tendency of borrowers to engage in risky activities that will make it less likely they will repay their loans. Both adverse selection and moral hazard are problems because of the existence of asymmetric information, which means that borrowers know things about their ability to repay that lenders do not.

${ }^{23}$ Bernanke and Kuttner (2005) follow Patelis (1997) in using the Campbell and Ammer (1993) methodology to decompose stock returns into changes in the discount factor (interest rates), expected dividends, or expected excess returns.

${ }^{24}$ Ammer, Vega, and Wongswan (2010) also consider the impact of path shocks described by Gürkaynak, Sack, and Swanson (2005). But, consistent with Gürkaynak, Sack, and Swanson's (2005) results, path shocks have little effect on equity, so Ammer, Vega, and Wongswan (2010) report only the results for the target shocks.

25 If the FOMC follows a "policy rule" that links policy to economic conditions (e.g., a Taylor rule), then a forecast of economic conditions would imply a policy forecast and vice versa. Faust, Swanson, and Wright (2004) find little evidence that Federal Reserve policy surprises can be used to improve forecasts of statistical releases, which suggests that the Federal Reserve does not necessarily have superior information about the state of the economy.

${ }^{26} \mathrm{Kool}$ and Thornton (2012), however, argue for a more skeptical view. Their study of forward guidance in New Zealand, Norway, Sweden, and the United States finds limited evidence that forward guidance improves the private sector's ability to forecast monetary policy.

27 Gürkaynak, Sack, and Swanson's (2005) two-factor model is arguably very similar to Bernanke and Kuttner's (2005) use of level and timing shocks in their study of equity reactions. In fact, the two sets of explanatory variables span the same space.

28 The authors thank Brian Swanson for suggesting this exercise and interpretation.

${ }^{29}$ The negative "Target" coefficients in Table 6, which would imply a perverse exchange rate response to interest rates, are the product of the use of noisy daily data. Use of intraday exchange rate data produces positive coefficients, as expected.

${ }^{30}$ Neely (2013) characterizes the impact of the Federal Reserve's unconventional policies on international bond yields and exchange rates. Bauer and Neely (2013) investigate the channels through which such effects occur.

${ }^{31}$ An estimator is consistent if it converges in probability to the parameter as the sample size increases. 


\section{Fawley and Neely}

\section{REFERENCES}

Ammer, John; Vega, Clara and Wongswan, Jon. “International Transmission of U.S. Monetary Policy Shocks: Evidence from Stock Prices." Journal of Money, Credit, and Banking, September 2010, 42(Suppl. s1), pp. 179-98.

Andersen, Torben G.; Bollerslev, Tim; Diebold, Francis X. and Vega, Clara. "Micro Effects of Macro Announcements: Real-Time Price Discovery in Foreign Exchange." American Economic Review, March 2003, 93(1), pp. 38-62.

Barro, Robert J. “Unanticipated Money, Output, and the Price Level.” Journal of Political Economy, August 1978, 86, pp. 549-80.

Basistha, Arabinda and Kurov, Alexander. "Macroeconomic Cycles and the Stock Market's Reaction to Monetary Policy." Journal of Banking and Finance, December 2008, 32(12), pp. 2606-16.

Bauer, Michael D. and Neely, Christopher J. "International Channels of the Fed's Unconventional Monetary Policy." Federal Reserve Bank of St. Louis Working Paper No. 2012-028D, December 12, 2013; http://research.stlouisfed.org/wp/2012/2012-028.pdf.

Bernanke, Ben S. and Blinder, Alan S. "The Federal Funds Rate and the Channels of Monetary Transmission." American Economic Review, September 1992, 82(4), pp. 901-21.

Bernanke, Ben S. and Kuttner, Kenneth N. "What Explains the Stock Market's Reaction to Federal Reserve Policy?" Journal of Finance, June 2005, 60(3), pp. 1221-57.

Bernanke, Ben S. and Mihov, Ilian. "Measuring Monetary Policy." Quarterly Journal of Econometrics, August 1998, 113(3), pp. 869-902.

Bomfim, Antulio N. "Pre-Announcement Effects, News Effects, and Volatility: Monetary Policy and the Stock Market." Journal of Banking and Finance, January 2003, 27(1), pp. 133-51.

Campbell, Jeffrey R.; Evans, Charles L.; Fisher, Jonas D.M. and Justiniano, Alejandro. "Macroeconomic Effects of Federal Reserve Forward Guidance." Brookings Papers on Economic Activity, Spring 2012, pp. 1-80.

Campbell, John Y. and Ammer, John. "What Moves the Stock and Bond Markets? A Variance Decomposition for Long-Term Asset Returns." Journal of Finance, March 1993, 48(1), pp. 3-37.

Campbell, John Y. and Shiller, Robert J. "The Dividend-Price Ratio and Expectations of Future Dividends and Discount Factors." Review of Financial Studies, 1988, 1(3), pp. 195-228.

Carlson, John B.; Craig, Ben R. and Melick, William R. "Recovering Market Expectations of FOMC Rate Changes with Options on Federal Funds Futures." Journal of Futures Markets, December 2005, 25(12), pp. 1203-42.

Christiano, Lawrence J.; Eichenbaum, Martin and Evans, Charles L. "Monetary Policy Shocks: What Have We Learned and to What End?" in John B. Taylor and Michael J. Woodford, eds., Handbook of Macroeconomics. Volume 1 A. Amsterdam: Elsevier B.V., 1999, pp. 65-148.

Cochrane, John H. and Piazzesi, Monika. "The Fed and Interest Rates: A High-Frequency Identification." American Economic Review, May 2002, 92(2), pp. 90-95.

Cook, Timothy and Hahn, Thomas. "The Information Content of Discount Rate Announcements and Their Effect on Market Interest Rates." Journal of Money, Credit, and Banking, May 1988, 20(2), pp. 167-80.

Cook, Timothy and Hahn, Thomas. "The Effect of Changes in the Federal Funds Rate Target on Market Interest Rates in the 1970s." Journal of Monetary Economics, November 1989, 24(3), pp. 331-51.

Cornell, Bradford. "Money Supply Announcements, Interest Rates, and Foreign Exchange." Journal of International Money and Finance, August 1982, 1, pp. 201-08.

Cornell, Bradford. "The Money Supply Announcements Puzzle: Review and Interpretation." American Economic Review, September 1983, 73(4), pp. 644-57.

Craine, Roger and Martin, Vance L. "International Monetary Policy Surprise Spillovers." Journal of International Economics, May 2008, 75(1), pp. 180-96.

DeLong, J.B. "America's Peacetime Inflation: The 1970s," in Christina D. Romer and David H. Romer, (eds.), Motivation and Strategy. NBER Studies in Business Cycles. Volume 30. Chicago: University of Chicago Press, 1997. 
Edelberg, Wendy and Marshall, David. "Monetary Policy Shocks and Long-Term Interest Rates." Federal Reserve Bank of Chicago Economic Perspectives, March 1996, 20(2), pp. 2-17;

http://www.chicagofed.org/digital_assets/publications/economic_perspectives/1996/epmar96a.pdf.

Ehrmann, Michael and Fratscher, Marcel. "Taking Stock: Monetary Policy Transmission to Equity Markets." Journal of Money, Credit, and Banking, August 2004, 36(4), pp. 719-37.

Ehrmann, Michael and Fratzscher, Marcel. "Global Financial Transmission of Monetary Policy Shocks." Oxford Bulletin of Economics and Statistics, December 2009, 71(6), pp. 739-59.

Ellingsen, Tore and Soderstrom, Ulf. "Monetary Policy and the Bond Market." IGIER Working paper, Innocenzo Gasparini Institute for Economic Research, 2004.

Emmons, William R.; Lakdawala, Aeimit K. and Neely, Christopher J. "What Are the Odds? Option-Based Forecasts of FOMC Target Changes." Federal Reserve Bank of St. Louis Review, November/December 2006, 88(6), pp. 543-61; http://research.stlouisfed.org/publications/review/06/11/Emmons.pdf.

Evans, Charles L. and Marshall, David A. "Monetary Policy and the Term Structure of Nominal Interest Rates: Evidence and Theory." Carnegie-Rochester Conference Series on Public Policy, December 1998, 49(1), pp. 53-111.

Fama, Eugene F. “Efficient Capital Markets: A Review of Theory and Empirical Work." Journal of Finance, May 1970, 25(2), pp. 383-417.

Fatum, Rasmus, and Scholnick, Barry. “Do Exchange Rates Respond to Day-to-Day Changes in Monetary Policy Expectations When No Monetary Policy Changes Occur?" Journal of Money, Credit, and Banking, September 2006, 38(6), pp. 1641-57.

Fatum, Rasmus and Scholnick, Barry. "Monetary Policy News and Exchange Rate Responses: Do Only Surprises Matter?" Journal of Banking and Finance, June 2008, 32(6), pp. 1076-86.

Faust, Jon; Rogers, John H.; Wang, Shing-Yi B. and Wright, Jonathan H. "The High-Frequency Response of Exchange Rates and Interest Rates to Macroeconomic Announcements." Journal of Monetary Economics, 2007, 54, pp. 1051-68.

Faust, Jon; Swanson, Eric T. and Wright, Jonathan H. “Do Federal Reserve Policy Surprises Reveal Superior Information about the Economy?" Contributions in Macroeconomics, October 2004, 4(1), pp. 1-31.

Federal Open Market Committee. "Press Release." February 4, 1994a; http://www.federalreserve.gov/fomc/19940204default.htm.

Federal Open Market Committee. "Press Release." August 16, 1994b; http://www.federalreserve.gov/fomc/19940816default.htm.

Federal Open Market Committee. "Conference Call." September 21, 1998; http://www.federalreserve.gov/monetarypolicy/files/FOMC19980921 confcall.pdf.

Fleming, Michael J. and Piazzesi, Monika. "Monetary Policy Tick-by-Tick." Unpublished manuscript, Federal Reserve Bank of New York, August 2005.

Friedman, Benjamin M. and Kuttner, Kenneth N. "Implementation of Monetary Policy: How Do Central Banks Set Interest Rates?" in Friedman, Benjamin M. and Woodford, Michael (eds.)., Handbook of Monetary Economics. Volume 3B. Amsterdam: North-Holland, 2011, pp. 1345-438.

Friedman, Milton. "The Role of Monetary Policy." American Economic Review, March 1968, 58(1), pp. 1-17.

Gürkaynak, Refet S.; Sack, Brian P. and Swanson, Eric T. "Do Actions Speak Louder Than Words? The Response of Asset Prices to Monetary Policy Actions and Statements." International Journal of Central Banking, May 2005, 1(1), pp. 55-93.

Gürkaynak, Refet S.; Sack, Brian P. and Swanson, Eric T. "Market-Based Measures of Monetary Policy Expectations." Journal of Business and Economic Statistics, April 2007, 25(2), pp. 201-12.

Hamilton, James D. "Assessing Monetary Policy Effects Using Daily Federal Funds Futures Contracts." Federal Reserve Bank of St. Louis Review, July/August 2008, 90(4), pp. 377-93;

http://research.stlouisfed.org/publications/review/08/07/Hamilton.pdf. 


\section{Fawley and Neely}

Hamilton, James D. “Daily Changes in Fed Funds Futures Prices." Journal of Money, Credit, and Banking, June 2009, 41(4), pp. 567-82.

Hardouvelis, Gikas A. "Market Perceptions of Federal Reserve Policy and the Weekly Monetary Announcements." Journal of Monetary Economics, September 1984, 14(2), pp. 225-40.

Hausman, Joshua and Wongswan, Jon. "Global Asset Prices and FOMC Announcements." Journal of International Money and Finance, April 2011, 30, pp. 547-71.

Kool, Clemens J.M. and Thornton, Daniel L. “How Effective Is Central Bank Forward Guidance?" Federal Reserve Bank of St. Louis Working Paper No. 2012-063A, December 2012; http://research.stlouisfed.org/wp/2012/2012-063.pdf.

Kuttner, Kenneth N. "Monetary Policy Surprises and Interest Rates: Evidence from the Fed Funds Futures Market." Journal of Monetary Economics, June 2001, 47(3), pp. 523-44.

Litterman, Robert B. and Weiss, Laurence. “Money, Real Interest Rates, and Output: A Reinterpretation of Postwar U.S. Data." Econometrica, January 1985, 53(1), pp. 129-56.

McCallum, Bennett T. “A Reconsideration of Sims'Evidence Concerning Monetarism." Economic Letters, 1983, 13(2-3), pp. 167-71.

Meulendyke, Ann-Marie. U.S. Monetary Policy and Financial Markets. Federal Reserve Bank of New York, 1998; http://research.stlouisfed.org/aggreg/meulendyke.pdf.

Middeldorp, Menno. "FOMC Communication Policy and the Accuracy of Fed Funds Futures." Federal Reserve Bank of New York Staff Report No. 491, April 2011; http://www.newyorkfed.org/research/staff_reports/sr491.pdf.

Mishkin, Frederic S. "Symposium on the Monetary Transmission Mechanism." Journal of Economic Perspectives, Fall 1995, 9(4), pp. 3-10.

Neely, Christopher J. “Unconventional Monetary Policy Had Large International Effects." Federal Reserve Bank of St. Louis Working Paper No. 2010-018E, July 2010, updated August 2013; http://research.stlouisfed.org/wp/2010/2010-018.pdf.

Nelson, Edward. "The Great Inflation of the Seventies: What Really Happened?" B.E. Journal of Macroeconomics: Advances in Macroeconomics, July 2005a, 5(1), pp. 1-50.

Nelson, Edward. "Monetary Policy Neglect and the Great Inflation in Canada, Australia, and New Zealand." International Journal of Central Banking, May 2005b, 1(1), pp. 133-79.

Nelson, Edward and Nikolov, Kalin. "Monetary Policy and Stagflation in the U.K." Journal of Money, Credit, and Banking, June 2004, 36(3), pp. 293-318.

Patelis, Alex D. "Stock Return Predictability and the Role of Monetary Policy." Journal of Finance, December 1997, 52(5), pp. 1951-72.

Piazzesi, Monika and Swanson, Eric T. "Futures Prices as Risk-Adjusted Forecasts of Monetary Policy." Journal of Monetary Economics, May 2008, 55(4), pp. 677-91.

Poole, William and Rasche, Robert H. "Perfecting the Market's Knowledge of Monetary Policy." Journal of Financial Services Research, December 2000, 18(2-3), pp. 255-98.

Poole, William; Rasche, Robert H. and Thornton, Daniel L. "Market Anticipations of Monetary Policy." Federal Reserve Bank of St. Louis Review, July/August 2002, 84(4), pp. 65-93;

http://research.stlouisfed.org/publications/review/02/07/65-94PooleRasche.pdf.

Radecki, Laurence and Reinhart, Vincent R. "The Financial Linkages in the Transmission of Monetary Policy in the United States," in National Differences in Interest Rate Transmission. Basel: Bank for International Settlements, 1994, pp. 291-337.

Reichenstein, William. "The Impact of Money on Short-term Interest Rates." Economic Inquiry, January 1987, 25(1), pp. 67-82.

Rigobon, Roberto and Sack, Brian P. "The Impact of Monetary Policy on Asset Prices." Journal of Monetary Economics, November 2004, 51(8), pp. 1553-75. 
Rigobon, Roberto and Sack, Brian P. "Noisy Macroeconomic Announcements, Monetary Policy, and Asset Prices," in John Y. Campbell, ed., Asset Prices and Monetary Policy. Chicago: University of Chicago Press, 2008, pp. 335-70.

Roley, V. Vance and Sellon, Gordon H. Jr. "Monetary Policy Actions and Long Term Interest Rates." Federal Reserve Bank of Kansas City Economic Quarterly, Fourth Quarter 1995, 80, pp. 73-89;

http://www.kc.frb.org/publicat/econrev/pdf/4q95role.pdf.

Romer, Christina D. and Romer, David H. "Does Monetary Policy Matter? A New Test in the Spirit of Friedman and Schwartz," in Olivier Jean Blanchard and Stanley Fischer, eds., NBER Macroeconomics Annual 1989. Volume 4. Cambridge, MA: MIT Press, 1989, pp. 121-84.

Romer, Christina D. and Romer, David H. “Monetary Policy Matters." Journal of Monetary Economics, August 1994, 34(1), pp. 75-88.

Romer, Christina D. and Romer, David H. "A Rehabilitation of Monetary Policy in the 1950s." American Economic Review, May 2002, 92(2), pp. 121-27.

Rosa, Carlo. "Words That Shake Traders: The Stock Market's Reaction to Central Bank Communication in Real Time." Journal of Empirical Finance, December 2011a, 18(5), pp. 915-34.

Rosa, Carlo. “The Validity of the Event-Study Approach: Evidence from the Impact of the Fed's Monetary Policy on U.S. and Foreign Asset Prices." Economica, July 2011b, 78(311), pp. 429-39.

Rosa, Carlo. "The High-Frequency Response of Exchange Rates to Monetary Policy Actions and Statements." Journal of Banking and Finance, February 2011c, 35(2), pp. 478-89.

Sims, Christopher A. "Comparison of Interwar and Postwar Business Cycles: Monetarism Reconsidered." American Economic Review, May 1980, 70, pp. 250-57.

Strongin, Steven H. "The Identification of Monetary Policy Disturbances Explaining the Liquidity Puzzle." Journal of Monetary Economics, June 1995, 35(3), pp. 463-97.

Swanson, Eric T. "Have Increases in Federal Reserve Transparency Improved Private Sector Interest Rate Forecasts?" Journal of Money, Credit, and Banking, April 2006, 38(3), pp. 791-819.

Thornton, Daniel L. "The Borrowed-Reserves Operating Procedure: Theory and Evidence." Federal Reserve Bank of St. Louis Review, January/February 1988, 70(1), pp. 30-54; http://research.stlouisfed.org/publications/review/88/01/Borrowed_Jan_Feb1988.pdf.

Thornton, Daniel L. "The Information Content of Discount Rate Announcements: What Is Behind the Announcement Effect?" Journal of Banking and Finance, January 1998, 22(1), pp. 83-108.

Thornton, Daniel L. "The Codification of an FOMC Procedure." Federal Reserve Bank of St. Louis Monetary Trends, March 2001a; http://research.stlouisfed.org/publications/mt/20010301/cover.pdf.

Thornton, Daniel L. "The Federal Reserve's Operating Procedure, Non-Borrowed Reserves, Borrowed Reserves and the Liquidity Effect." Journal of Banking and Finance, September 2001 b, 25(9), pp. 1717-39.

Valente, Giorgio. "International Interest Rates and U.S. Monetary Policy Announcements: Evidence from Hong Kong and Singapore." Journal of International Money and Finance, October 2009, 28(6), pp. 920-40. 
